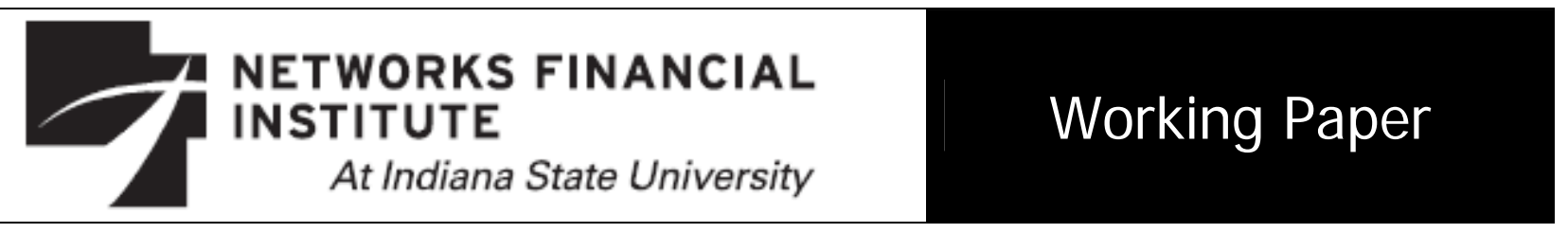

\title{
2007-WP-23
}

October 2007

\section{Credit Practices and Financial Education Needs of Midwest College Students}

\section{Angela C. Lyons}

Abstract: College students are facing a number of financial challenges, including rising college costs and subsequent escalation in student borrowing to finance their education. Financial aid has not kept pace with rising college costs, and fewer parents are helping to cover these costs, because they overextended themselves with debt during the 1990s. The end result is that an increasing number of students are turning to credit card debt to help finance their education. The growth in credit card usage among college students has generated concern that students' credit card behavior is putting them at greater risk for high debt levels and misuse and/or mismanagement of credit after graduation. The main objectives of this report are to 1 ) provide greater insight into the credit practices and financial education needs of Midwest college students and 2) to identify ways in which campus administrators and financial professionals can help students better manage their credit and avoid future misuse of credit down the road.

About the Author: Angela Lyons is a professor at the University of I llinois at UrbanaChampaign and an NFI Fellow. She received her Ph.D. in Economics from the University of Texas at Austin. Her research focuses on issues related to household economics, family finance, and financial education and program evaluation. Her current research examines issues related to household liquidity and credit access, health and financial strain, delinquency and bankruptcy, gender and marital differences in household financial decisions, and the credit usage and financial education needs of young adults. Dr. Lyons has been identified by the U.S. Government Accountability Office as one of twenty-three national leaders in financial education.

Keywords: Credit cards, credit debt, financial aid, financial literacy, college costs.

\footnotetext{
The views expressed are those of the individual author and do not necessarily reflect official positions of Networks Financial Institute. Please address questions regarding content to Angela Lyons at anglyons@illinois.edu. Any errors or omissions are the responsibility of the author.
}

NFI working papers and other publications are available on NFI's website (www.networksfinancialinstitute.org). Click "Research" and then "Publications/Papers." 


\section{Contents}

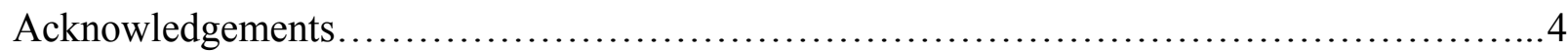

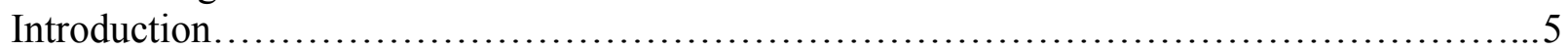

Research Objectives............................................................... 7

Survey Methodology.................................................................. 8

Student Demographics.......................................................... 11

Credit Practices of Students......................................................... 15

Financial Education Needs of Students.............................................. 21

The Consequences of Financial Strain on College Campuses..............................27

A Profile of Financially At-Risk Students.............................................29

Summary of Major Findings......................................................... 34

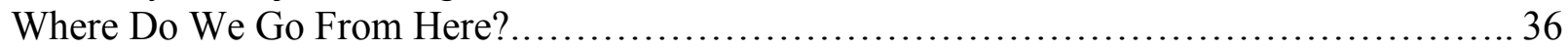

References...................................................................... 40

Appendix A: The Survey...................................................... 43

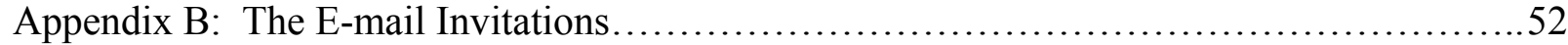

Appendix C: Credit Practices and Financial Education Needs by Campus.....................55 


\section{Tables}

Table 1: $\quad$ Composition of Sample and Response Rates............................. 9

Table 2: Demographic Profile of Students........................................ 13

Table 3: $\quad$ Credit Characteristics of Students.......................................... 16

Table 4: $\quad$ Preferences for the Delivery of Financial Information.........................22

Table 5: $\quad$ Knowledge and Preferences for Financial Education Topics ........................ 24

Table 6: $\quad$ Preferences for Personal Finance Courses................................. 26

Table 7: The Consequences of Student Financial Strain............................... 28

Table 8: $\quad$ Probit Models for Probability Student is Financially At-Risk.....................31

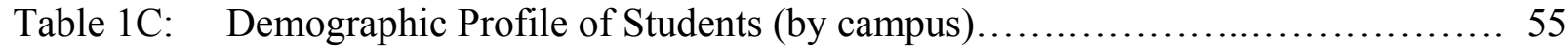

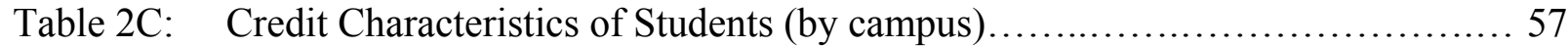

Table 3C: $\quad$ Preferences for the Delivery of Financial Information (by campus).............. 59

Table 4C: Knowledge and Preferences for Financial Education Topics (by campus)....... 60

Table 5C: Preferences for Personal Finance Courses (by campus)...........................61 61

Table 6C: The Consequences of Student Financial Strain (by campus).................. 62 


\section{Acknowledgements}

The author of this report would like to acknowledge a number of individuals who assisted in the design and implementation of the online survey on the credit practices and financial education needs of Midwest college students. Without their valuable input, this research would not be possible. In particular, I would like to thank:

- $\quad$ Orlo Austin, Director of the Office of Student Financial Aid, University of Illinois at Urbana-Champaign;

- $\quad$ Charles Boudreau, Director of Financial Aid, Illinois State University;

- $\quad$ Kathleen Brunson, Director of Financial Aid, Northern Illinois University;

- William Bushaw, Director of Financial Aid, Western Illinois University;

- $\quad$ Barry Chiswick, Professor and Director, Center for Economic Education, University of Illinois at Chicago;

- Michael Gutter, Assistant Professor, University of Wisconsin-Madison;

- $\quad$ Joyce Hall, Director of Financial Aid, Purdue University;

- Gerard Joseph, Director of Financial Aid, University of Illinois at Springfield;

- Dan Mann, Director of Financial Aid, Southern Illinois University-Carbondale;

- David Pardieck, Financial Assistance Director, Bradley University;

- Helen Roberts, Assistant Professor and Associate Director, Center for Economic Education, University of Illinois at Chicago;

- $\quad$ Tansel Yilmazer, Assistant Professor, Purdue University;

- $\quad$ Linda Yost, Director, Center for Economic Education, Bradley University.

The author graciously acknowledges the assistance and support of these individuals. Any errors are the sole responsibility of the author. 


\section{Introduction}

College students are facing a number of financial challenges. College costs have been rising at record levels, and students have had to borrow more to finance their education. At the same time, financial aid has not kept pace with rising college costs. In addition, fewer parents are helping to cover these costs, because they overextended themselves with debt during the 1990s (Johnstone, 1996; Fossey, 1998; Shenk, 2000; Asinof and Chaker, 2002). The end result is that an increasing number of students are turning to credit card debt to help finance their education (The Education Resources Institute and the Institute for Higher Education Policy, 1998; Shenk, 2000). The growth in credit card usage among college students has generated concern that students' credit card behavior is putting them at greater risk for high debt levels and misuse and/or mismanagement of credit after graduation. The recent economic slowdown and the rise in the number of bankruptcies for those under the age of 25 have intensified these concerns (United States General Accounting Office, 2001; Asinof and Chaker, 2002; Rohrke, 2002).

If used responsibly, credit cards can provide a number of advantages to college students. Credit cards can be a convenient means of payment, a useful tool for learning financial responsibility, a resource in case of emergencies, a means to establishing a good credit history, and a way to gain greater access to credit in the future. However, if credit cards are mismanaged or misused, the disadvantages can result in severe financial consequences. The convenience of credit may tempt students to live beyond their means. Excessive credit card debt and late payments can damage a student's credit rating and make it more difficult for them to obtain credit on down the road. In addition, students who are financially inexperienced may not understand the cumulative effect that interest rates can have on the amount of debt owed. Inexperience with credit and a lack of personal financial knowledge is likely to place some students at greater financial risk for having large, and perhaps unmanageable, debt burdens when they graduate. For those students who are receiving financial assistance in the form of need-based grants, federal loans for education, and/or federal work-study, there may be an added risk of future financial difficulty. Are students accruing more debt than they can handle? The results are mixed.

Recent media reports seem to suggest that college students are accruing too much credit card debt. Unfortunately, these reports often focus on anecdotal horror stories about students who have incurred excessively large amounts of debt. The seriousness of student credit card usage has also been exaggerated by recent commentary from college officials and policymakers, who feel strongly that students should have more limited access to credit. For this reason, researchers have begun to question whether growing concerns over rising credit card debt levels are warranted.

Several recent studies have attempted to determine whether college students are in fact incurring excessive amounts of credit card debt (Armstrong and Craven 1993; Xiao, Noring, and Anderson 1995; Allen and Jover 1997; The Education Resources Institute and the Institute for Higher Education Policy 1998; Hayhoe, Leach, and Turner 1999; Hayhoe, Leach, Turner, Bruin, and Lawrence 2000; Baek 2001; Joo, Grable, and Bagwell 2001; United States General Accounting 
Office 2001; Hayhoe 2002; Lyons and Andersen 2002; Staten and Barron 2002; Baum and O’Malley 2003; Lyons, 2004). These studies examine students' use of credit including: credit card ownership, the amount of credit card debt incurred, the types of credit cards held, and students' attitudes towards credit usage.

In general, these studies find that while the majority of college students now have credit cards, they appear to be using them responsibly and are not accumulating large amounts of debt. To summarize the key findings from these studies:

- $\quad$ Approximately, $80 \%$ of college students have at least one credit card.

- The vast majority obtain credit cards prior to college or during their freshman year.

- $\quad 6-14 \%$ have four or more credit cards.

- $\quad$ Over half of those with credit cards repay their balances in full each month.

- $\quad$ Only $14-16 \%$ report balances over $\$ 1000$ and about 5\% report balances over $\$ 3000$.

While these studies suggest that the majority of college students may be financially responsible, they also acknowledge that there are a growing number of college students who are "financially at-risk" for misusing and mismanaging credit. These students are at risk of not being able to repay their debts after graduation, either because of a lack of financial experience or a lack of funds. A few recent studies have attempted to identify who these students are and which groups are more likely than others to experience financial strain (Lyons and Andersen, 2002; Lyons and Hunt, 2003; Lyons, 2004). These studies show that college students who are financially at-risk for mismanaging and misusing credit are more likely to be financially independent, to receive need-based financial aid, and to hold $\$ 1000$ or more in debt other than student loans and credit card debt. These students are also more likely to be female, black, and/or Hispanic.

Identifying the credit practices and financial education needs of students who are most likely to be financially at-risk helps college campuses to provide the appropriate financial interventions. A number of studies have investigated how the financial knowledge and practices students develop affect their future financial well-being (Chen and Volpe, 1998; Doll, 2000; Pilcher and Haines, 2000; Varcoe et al., 2001; Weston, 2001; Lyons, 2003; Lyons and Hunt, 2003; Lyons, 2004). These studies show that formal financial education plays an important role in reducing students' financial management problems. Those who learn financial management skills at a younger age tend to do better financially than those who do not receive financial education (Varcoe et al., 2001).

Studies also reveal that students have specific preferences for how they receive financial education and from whom (Varcoe et al., 2001; Lyons and Hunt, 2003; Lyons, 2004). For example, Lyons (2003) finds that at-risk students are more likely than non at-risk students to prefer receiving financial information online and in the form of pamphlets and informational handouts rather than seminars, workshops, and/or counseling services. In another recent study, 
Lyons and Hunt (2003) show that community college students prefer to receive information on issues related to financial assistance and on how to become responsible credit consumers. These students also prefer to receive financial education in one-on-one discussions, small group settings and from financial aid officers.

While the findings from these studies provide insight into the financial education needs of students, they need to be interpreted with caution. Many are based on small sample sizes from particular campuses. In addition, none have conducted a thorough investigation of the financial education needs of financially at-risk students.

- $\quad$ Are students incurring too much credit card debt and/or other debt?

- Who are the students most at risk?

- How can college campuses help at-risk students better manage their finances while in school so that when they graduate they are able to repay their debts?

- What specifically can campus administrators and other financial professionals do to offer the appropriate kinds of help?

These are the issues addressed in this report.

\section{Research Objectives}

In the Spring of 2003, an online survey was launched at the University of Illinois at UrbanaChampaign to investigate the credit practices and financial education needs of college students in the Midwest. The purpose of this report is to present the survey findings. Specifically, the main objectives are to:

- Provide a detailed description of the credit card usage and financial practices of college students in the Midwest.

- Identify and characterize those students who are most at risk for mismanaging and misusing credit.

- Identify some of the hidden consequences of financial mismanagement for students.

- Discuss resources and services that can be offered to college students to help them better manage their credit card debt and other finances.

The ultimate goal is to make recommendations to campus administrators and financial professionals on how they can use this information to develop resources that address the specific 
financial education needs of students who are financially at-risk. Appropriate interventions are needed to insure that these students are not at a financial disadvantage when they graduate and are able to make informed financial decisions.

The next section describes the survey methodology and characterizes the student sample. The remaining sections provide detailed analysis of students' credit practices and financial education needs. A description of the students who are financially at-risk is also provided. Finally, recommendations about financial services that could help those most at risk are included at the end.

\section{Survey Methodology}

As previously mentioned, the University of Illinois at Urbana-Champaign launched a survey in the Spring of 2003 to obtain feedback regarding the credit practices and financial education needs of college students in the Midwest. Undergraduate students were contacted on ten campuses in the state of Illinois and two others. The campuses included Bradley University, Illinois State University, Northern Illinois University, Purdue University, Southern Illinois University at Carbondale, University of Illinois at Chicago, University of Illinois at Springfield, University of Illinois at Urbana-Champaign, University of Wisconsin-Madison, and Western Illinois University.

The online survey was designed using a software program called Infopoll Designer $\mathrm{C}$. A unique feature of this software program is that it offers the option to view the data in real time. In addition, raw data is saved online and can be viewed in charts and graphs at any time even after removing the survey from the web. A disadvantage to using this type of online survey is that participants can skip questions or sections, thus the number of actual answers to each question varies and, of course, all survey information was self-reported.

The survey was divided into three sections: Current Credit Card Usage and Knowledge, Financial Education, Some Information About You (see Appendix A for the survey instrument). There were 52 survey questions. To comply with human subject guidelines for each campus, a special permission form explaining the intent of the survey was developed. Because of the sensitive nature of some of the questions on the survey, extra precautions were taken to insure that no personal information would be connected with students' names or e-mail addresses.

Instead of contacting a random sample of students on each campus, approval was obtained from campus administrators to send e-mails to all undergraduate students who had a registered e-mail at each location. Approximately 168,000 students were invited to participate in the study.

Three mass e-mails were sent out to the students. The initial e-mail invited students to participate in the study and the other two e-mails were sent as reminders (see Appendix B for the 
e-mails). The survey was posted at the beginning of February on a server hosted by the University of Illinois at Urbana-Champaign for a period of 30 days. Students who completed the survey were give the option to participate in a prize drawing for three $\$ 200$ gift certificates to BEST BUY. The winners were randomly selected from the pool of students who submitted their e-mail addresses to participate in the drawing.

On the survey's closing date, the data were downloaded from the server and the website was closed. The response rate for the survey was approximately $17.6 \%$, or 29,474 student responses. Of the 29,474 students who responded to the survey, 26,896 were valid responses. 2,578 student observations ( $8.7 \%$ of the sample) had to be dropped, primarily due to missing information. Some of these observations were also removed because a few students had either submitted their completed survey information multiple times or submitted blank surveys.

See Table 1 for the sample composition and response rates for each campus. This table includes the total number of students sampled on each campus, the total number of students who responded, the overall response rate, the number of observations dropped, the number of students included in the final sample, and the percentage composition of students from each campus.

\section{Table 1: Composition of Sample and Response Rates (Students from 10 College Campuses)}

\begin{tabular}{|c|c|c|c|c|c|c|}
\hline & $\begin{array}{c}\text { Total } \\
\text { number } \\
\text { sampled } \\
(\#)\end{array}$ & $\begin{array}{l}\text { Total } \\
\text { number of } \\
\text { responses } \\
\text { (\#) }\end{array}$ & $\begin{array}{l}\text { Overall } \\
\text { response } \\
\text { rate } \\
(\%)\end{array}$ & $\begin{array}{l}\text { Number } \\
\text { of obs } \\
\text { dropped } \\
\text { (\#) }\end{array}$ & $\begin{array}{l}\text { Number } \\
\text { in final } \\
\text { sample } \\
\quad \#)\end{array}$ & $\begin{array}{c}\text { Percent } \\
\text { of final } \\
\text { sample } \\
(\%)\end{array}$ \\
\hline Bradley University & 2,504 & 547 & 21.8 & 34 & 513 & 1.9 \\
\hline Illinois State University & 19,256 & 3,056 & 15.9 & 434 & 2,622 & 9.7 \\
\hline Northern Illinois University & 18,000 & 1,587 & 8.8 & 327 & 1,260 & 4.7 \\
\hline Southern Illinois University at Carbondale & 13,628 & 2,043 & 15.0 & 173 & 1,870 & 7.0 \\
\hline University of Illinois at Chicago & 14,902 & 2,242 & 15.0 & 183 & 2,059 & 7.7 \\
\hline University of Illinois at Springfield & 4,397 & 275 & 6.3 & 106 & 169 & 0.6 \\
\hline University of Illinois at Urbana-Champaign & 30,000 & 7,324 & 24.4 & 464 & 6,860 & 25.5 \\
\hline Western Illinois University & 10,047 & 2,046 & 20.4 & 135 & 1,911 & 7.1 \\
\hline University of Wisconsin at Madison & 26,758 & 6,205 & 23.2 & 386 & 5,819 & 21.6 \\
\hline Purdue University & 28,169 & 4,149 & 14.7 & 336 & 3,813 & 14.2 \\
\hline Total Sample & 167,661 & 29,474 & 17.6 & 2,578 & 26,896 & 100.0 \\
\hline
\end{tabular}




\section{Survey Limitations}

Our description of the survey methodology would not be complete without a discussion of some of the survey's limitations. Most of the limitations result directly from the fact that students were notified via e-mail and the survey was conducted online.

- While all of the campuses included in this study had some type of central e-mail list, the quality of these lists varied across campuses. Some e-mail lists were regularly updated. However, others were not. For example, lists from Northern Illinois University and the University of Illinois at Springfield were not as accurate as lists from University of Illinois at Urbana-Champaign and the University of Wisconsin-Madison. The quality of these lists is reflected in the response rates. One must therefore be cautious when interpreting and comparing findings across campuses.

- Another limitation is that anyone who knew the web address of the survey, regardless of whether or not they were in the sample, could submit the survey. This could enable anyone to corrupt the data. For example, participants could technically respond as many times as they wanted to the survey and a few did. However, it was fairly easy to identify these students given their responses to particular survey questions. An ID and password could have been provided to each prospective participant. However, given the sensitive nature of the survey topics and the guidelines set by human subjects, it was decided that no identifying elements would be used.

- $\quad$ Since the survey dealt with sensitive issues concerning personal money matters, some students may have felt uncomfortable answering the survey and chose not to participate. Some may have also been concerned about whether or not the data would in fact be kept confidential. These factors along with the recent increase in the number of online surveys may have affected the student response rate.

- $\quad$ Finally, it is important to note that all of the survey questions were self-reported, which could have resulted in the mis-reporting or under-reporting of credit usage and other money management inquiries. In other words, the "actual" credit card usage and financial practices of students may be different than what they reported. Due to perhaps societal pressures or standards, some students may have reported what they believed to be was the "correct" answer rather than what actually was the correct answer.

Overall, regardless of these limitations, the results from the survey provide significant insight into the credit practices and financial education needs of college students in the Midwest. 


\section{Student Demographics}

The tables that follow provide an overview of the demographic and financial characteristics of the entire sample and of specific groups of students who are likely to be at greater financial risk than others for misusing and mismanaging credit. Appendix $C$ presents the findings for each campus.

For the purposes of this report, students are identified as being financially at-risk if they have one or more of the following four characteristics: 1) credit card balances of $\$ 1000$ or more, 2) delinquent on their credit card payments by two months or more, 3 ) have reached the limit on their credit cards, and 4) only pay off their credit card balances some of the time or never.

The measures of financial risk were constructed based on previous research which has consistently identified credit misuse and/or mismanagement according to these four characteristics (i.e. The Education Resources Institute and the Institute for Higher Education Policy, 1998; United States General Accounting Office, 2001; Lyons and Andersen, 2002; Baum and O'Malley, 2003; Lyons and Hunt, 2003; Lyons, 2004). These measures clearly identify students who are having difficulty managing their credit and/or repaying their credit card balances. Each measure captures a slightly different aspect of financial risk - the magnitude of how much is owed, the ability to make timely payments, future ability to borrow, and the ability to repay debts incurred. Students who are classified as financially at-risk may have one or more of these characteristics.

In each table that follows, the first set of columns presents the findings for the entire sample. The next three columns present the results for students with credit cards, students with credit cards and no at-risk characteristics, and students with credit cards and at least one at-risk characteristic. The remaining columns present information according to the four at-risk characteristics. Of the 26,896 students who comprise the working sample, $72.4 \%$ reported having at least one credit card. Of those with a credit card, $42.9 \%$ indicated that they engage in at least one of the four at-risk behaviors.

Table 2 provides general demographic information. The first column of Table 2 reports the findings for the entire sample. With respect to year in school, $23.6 \%$ of the sample was freshmen, $22.0 \%$ was sophomores, $25.0 \%$ was juniors, and $29.4 \%$ was seniors. Only $5 \%$ of the sample was over the age of 25 . In regards to gender and ethnicity, almost $60 \%$ of the students were female and $79.3 \%$ were white, $4.8 \%$ were black, $9.0 \%$ were Asian, and $4.1 \%$ were Hispanic. Less than 5\% reported being married. With respect to academic performance, $71.1 \%$ reported having a grade point average above 3.0.

Since most of the students included in this study were from state universities, it should not be surprising that over $80.0 \%$ were in-state residents while only $10.9 \%$ were out-of-state residents and $2.6 \%$ reported that they were international students. Interestingly, almost a quarter of the students indicated that they were the first person in their immediate family to attend college, and 
almost 20\% reported being financially independent from their parents such that their parents were unable to claim them on their tax return. Less than half of the students in the sample (44.4\%) rented an apartment and 89.0\% reported that their parents owned their own home.

With respect to employment and income, the majority of students in the sample worked 20 hours or less per week $(88.1 \%)$ and most earned $\$ 500$ or less each month $(82.8 \%)$. A little over half of the students $(57.0 \%)$ indicated that they came from a home town with a population of 20,000 or more. (The demographic findings for each campus can be found in Appendix $C$, Table 1C.)

The remaining columns in Table 2 focus on the demographics of students according to their financial risk status. Several findings are worth noting.

- $\quad$ First, students with credit cards who exhibit at-risk behaviors are more likely than students with credit cards who do not exhibit at-risk behaviors to be older, Black, Hispanic, to have lower grade point averages, and/or to rent an apartment.

- $\quad$ They are also more likely than other students to be the first person in their immediate family to attend college and to be financially independent from their parents.

- With respect to employment and income, students with credit cards who exhibit at-risk behaviors are more likely to be working and to be working more hours per week than students with credit cards who do exhibit at-risk behaviors. Given these findings, it is not surprising that their monthly earnings are also higher, most likely because they are trying to repay their debt obligations. 
Table 2: Demographic Profile of Students

\begin{tabular}{|c|c|c|c|c|c|c|c|c|}
\hline \multirow[b]{2}{*}{ Variable (mean/percentage) } & \multirow[b]{2}{*}{$\begin{array}{c}\text { All } \\
\text { Students } \\
(\mathrm{N}=\mathbf{2 6 , 8 9 6 )}\end{array}$} & \multirow[b]{2}{*}{$\begin{array}{c}\text { Students } \\
\text { w/ cc } \\
(\mathrm{N}=19,477)\end{array}$} & \multirow[b]{2}{*}{$\begin{array}{c}\text { Not at-risk } \\
\text { w/ cc } \\
(\mathrm{N}=11,124)\end{array}$} & \multirow[b]{2}{*}{$\begin{array}{c}\text { At-risk } \\
\text { w/cc } \\
(\mathrm{N}=8,353)\end{array}$} & \multicolumn{4}{|c|}{ Groups of At-Risk Students } \\
\hline & & & & & $\begin{array}{c}\text { Credit card } \\
\text { debt } \geq \$ 1000 \\
(N=4,233)\end{array}$ & $\begin{array}{l}\text { Delinquent } \\
\text { on payments } \\
(\mathrm{N}=1,666)\end{array}$ & $\begin{array}{c}\text { Reached } \\
\text { limit } \\
(\mathrm{N}=4,101)\end{array}$ & $\begin{array}{l}\text { Do not pay } \\
\text { balance in full } \\
(\mathrm{N}=6,445)\end{array}$ \\
\hline \multicolumn{9}{|l|}{ Demographics } \\
\hline Freshmen & 23.6 & 17.3 & 21.8 & 11.2 & 3.6 & 6.9 & 11.4 & 9.6 \\
\hline Sophomore & 22.0 & 20.5 & 23.5 & 16.5 & 10.9 & 13.3 & 17.7 & 15.0 \\
\hline Junior & 25.0 & 27.4 & 25.9 & 29.3 & 30.8 & 30.4 & 29.5 & 29.6 \\
\hline Senior & 29.4 & 34.9 & 28.8 & 43.0 & 54.7 & 49.3 & 41.5 & 45.8 \\
\hline Age $>25$ & 5.1 & 5.9 & 2.2 & 10.9 & 15.5 & 14.9 & 11.7 & 11.7 \\
\hline Female & 58.8 & 58.9 & 58.4 & 59.6 & 59.3 & 63.9 & 59.4 & 62.2 \\
\hline White & 79.3 & 79.1 & 83.6 & 73.1 & 72.1 & 60.5 & 70.5 & 73.6 \\
\hline Black & 4.8 & 4.3 & 1.3 & 8.4 & 9.7 & 17.6 & 9.9 & 9.8 \\
\hline Asian & 9.0 & 9.7 & 10.2 & 9.2 & 8.0 & 9.8 & 9.8 & 7.2 \\
\hline Hispanic & 4.1 & 4.0 & 2.4 & 6.1 & 6.7 & 8.0 & 6.1 & 6.3 \\
\hline Other race & 2.8 & 2.8 & 2.5 & 3.3 & 3.5 & 4.1 & 3.8 & 3.1 \\
\hline Married & 3.9 & 4.6 & 2.2 & 7.8 & 11.9 & 7.8 & 7.6 & 8.1 \\
\hline GPA (3.6-4.0) & 28.5 & 28.4 & 33.9 & 21.0 & 20.1 & 13.7 & 19.4 & 18.8 \\
\hline GPA $(3.0-3.5)$ & 42.6 & 43.5 & 44.5 & 42.1 & 40.9 & 35.7 & 40.4 & 40.9 \\
\hline GPA (2.0-2.9) & 27.3 & 26.9 & 20.6 & 35.3 & 37.6 & 48.0 & 38.1 & 38.4 \\
\hline $\operatorname{GPA}(<2.0)$ & 1.6 & 1.2 & 0.9 & 1.6 & 1.4 & 2.6 & 2.1 & 1.8 \\
\hline In-state resident & 86.5 & 85.9 & 84.7 & 87.5 & 90.1 & 89.8 & 87.0 & 90.0 \\
\hline Out-of state resident & 10.9 & 11.3 & 12.9 & 9.2 & 7.5 & 7.1 & 9.2 & 7.9 \\
\hline International student & 2.6 & 2.8 & 2.4 & 3.3 & 2.4 & 3.1 & 3.9 & 2.1 \\
\hline 1st generation college student & 22.9 & 23.3 & 20.0 & 27.6 & 31.3 & 32.4 & 28.4 & 29.1 \\
\hline Financially independent & 19.5 & 21.9 & 13.4 & 33.4 & 44.6 & 42.0 & 36.2 & 35.0 \\
\hline Rents an apartment & 44.4 & 49.8 & 45.6 & 55.5 & 62.5 & 60.2 & 55.8 & 57.3 \\
\hline Parents own home & 89.0 & 89.4 & 92.7 & 85.1 & 83.4 & 78.2 & 83.7 & 84.1 \\
\hline
\end{tabular}


Table 2 (conti.): Demographic Profile of Students

\begin{tabular}{|c|c|c|c|c|c|c|c|c|}
\hline \multirow[b]{2}{*}{ Variable (mean/percentage) } & \multirow[b]{2}{*}{$\begin{array}{c}\text { All } \\
\text { Students } \\
(\mathrm{N}=\mathbf{2 6 , 8 9 6 )}\end{array}$} & \multirow[b]{2}{*}{$\begin{array}{c}\text { Students } \\
\text { w/ cc } \\
(\mathrm{N}=19,477)\end{array}$} & \multirow[b]{2}{*}{$\begin{array}{c}\text { Not at-risk } \\
\text { w/ cc } \\
(\mathrm{N}=11,124)\end{array}$} & \multirow[b]{2}{*}{$\begin{array}{c}\text { At-risk } \\
\text { w/cc } \\
(\mathrm{N}=8,353)\end{array}$} & \multicolumn{4}{|c|}{ Groups of At-Risk Students } \\
\hline & & & & & $\begin{array}{c}\text { Credit card } \\
\text { debt } \geq \$ 1000 \\
(\mathrm{~N}=4,233)\end{array}$ & $\begin{array}{l}\text { Delinquent } \\
\text { on payments } \\
(\mathrm{N}=1,666)\end{array}$ & $\begin{array}{c}\text { Reached } \\
\text { limit } \\
(\mathrm{N}=4,101)\end{array}$ & $\begin{array}{l}\text { Do not pay } \\
\text { balance in full } \\
(\mathrm{N}=6,445)\end{array}$ \\
\hline \multicolumn{9}{|l|}{ Employment } \\
\hline Not working & 43.6 & 40.1 & 46.3 & 31.9 & 24.5 & 30.3 & 31.1 & 29.0 \\
\hline Working 1-10 hrs/wk & 19.4 & 19.2 & 21.7 & 15.8 & 13.8 & 12.7 & 15.7 & 15.4 \\
\hline Working 11-20 hrs/wk & 25.1 & 26.8 & 23.7 & 30.9 & 32.6 & 33.1 & 30.9 & 32.4 \\
\hline Working 21-30 hrs/wk & 6.8 & 7.8 & 5.4 & 11.0 & 14.0 & 13.0 & 11.6 & 12.1 \\
\hline Working $>30 \mathrm{hrs} / \mathrm{wk}$ & 5.1 & 6.1 & 2.9 & 10.4 & 15.1 & 11.0 & 10.7 & 11.1 \\
\hline \multicolumn{9}{|l|}{ Monthly income } \\
\hline Income $(\$ 1-\$ 249)$ & 19.5 & 18.9 & 20.5 & 16.9 & 14.2 & 17.6 & 16.8 & 17.2 \\
\hline Income (\$250-\$499) & 20.9 & 21.9 & 20.7 & 23.4 & 23.9 & 24.9 & 23.7 & 24.4 \\
\hline Income (\$500-\$749) & 8.6 & 9.8 & 7.5 & 12.7 & 15.3 & 12.1 & 13.0 & 13.7 \\
\hline Income (\$750-\$999) & 3.7 & 4.4 & 3.0 & 6.3 & 8.3 & 6.2 & 6.4 & 6.7 \\
\hline Income ( $\geq \$ 1000)$ & 4.9 & 6.0 & 3.1 & 9.8 & 14.6 & 9.4 & 10.0 & 9.9 \\
\hline \multicolumn{9}{|l|}{ Regional information } \\
\hline Rural area (pop under 2,500) & 12.3 & 11.8 & 12.2 & 11.3 & 11.2 & 10.0 & 11.0 & 11.4 \\
\hline Town/City (pop 2,500-19,999) & 30.6 & 30.3 & 30.6 & 29.9 & 30.2 & 28.8 & 29.2 & 30.2 \\
\hline City (pop 20,000-99,999) & 35.1 & 35.5 & 37.1 & 33.3 & 32.4 & 30.4 & 33.9 & 33.5 \\
\hline City (pop 100,000 or more) & 21.9 & 22.1 & 19.8 & 25.2 & 25.9 & 30.6 & 25.8 & 24.6 \\
\hline
\end{tabular}




\section{Credit Practices of Students}

\section{Credit Card Usage}

Table 3 summarizes the credit practices of the entire sample and compares them to those who have been identified as financially at-risk. The results from Table 3 indicate the following:

- $\quad 78.8 \%$ of the total number of students who were sampled indicated that they held at least one credit card.

- $\quad$ About $19.0 \%$ reported holding 4 or more credit cards.

- $\quad 15.7 \%$ of the students sampled indicated that they owed $\$ 1000$ or more in credit card debt, and $7.5 \%$ owed $\$ 3000$ or more.

- The majority of students (76.0\%) reported paying off their balances in full each month.

- $\quad 15.3 \%$ reached the borrowing limit on their cards and were "maxed out."

- $6.2 \%$ were late on their credit card payments by two months or more.

- $\quad 86.1 \%$ of students with credit cards obtained their first credit cards either before arriving on campus or during the first year of college.

Overall, these findings are fairly consistent with the literature suggesting that the credit practices of students in the Midwest are similar to those of other college campuses. Students in the Midwest may be holding more credit cards though. They may also be more likely to have balances over $\$ 3000$. However, it would appear that they are more likely to pay them off in full. Recall from past studies that:

- $\quad$ Between 6.0 and 14.0\% have four or more credit cards (compared to 19.0\% for Midwest students.)

- Over half repay their balances in full each month (compared to $76.0 \%$ for Midwest students.) 
Table 3: Credit Characteristics of Students

\begin{tabular}{|c|c|c|c|c|c|c|c|c|}
\hline \multirow[b]{2}{*}{ Variable (mean/percentage) } & \multirow[b]{2}{*}{$\begin{array}{c}\text { All } \\
\text { Students } \\
(\mathbf{N}=\mathbf{2 6 , 8 9 6 )}\end{array}$} & \multirow[b]{2}{*}{$\begin{array}{c}\text { Students } \\
\text { w/ cc } \\
(\mathrm{N}=19,477)\end{array}$} & \multirow[b]{2}{*}{$\begin{array}{c}\text { Not at-risk } \\
\text { w/ cc } \\
(\mathrm{N}=11,124)\end{array}$} & \multirow[b]{2}{*}{$\begin{array}{c}\text { At-risk } \\
\text { w/cc } \\
(\mathrm{N}=8,353)\end{array}$} & \multicolumn{4}{|c|}{ Groups of At-Risk Students } \\
\hline & & & & & $\begin{array}{c}\text { Credit card } \\
\text { debt } \geq \$ 1000 \\
(\mathrm{~N}=4,233)\end{array}$ & $\begin{array}{l}\text { Delinquent } \\
\text { on payments } \\
(\mathrm{N}=1,666)\end{array}$ & $\begin{array}{c}\text { Reached } \\
\text { limit } \\
(\mathrm{N}=4,101)\end{array}$ & $\begin{array}{l}\text { Do not pay } \\
\text { balance in full } \\
(\mathrm{N}=6,445)\end{array}$ \\
\hline Have a credit card(s) & 72.4 & 100.0 & 100.0 & 100.0 & 100.0 & 100.0 & 100.0 & 100.0 \\
\hline \multicolumn{9}{|l|}{ Credit card usage } \\
\hline 4 or more credit cards & 18.9 & 26.0 & 18.7 & 35.7 & 51.9 & 36.0 & 36.6 & 37.8 \\
\hline Credit card debt $\geq \$ 1000$ & 15.7 & 21.7 & 0.0 & 50.7 & 100.0 & 58.1 & 52.9 & 56.0 \\
\hline Credit card debt $\geq \$ 3000$ & 7.5 & 10.4 & 0.0 & 24.2 & 47.7 & 33.8 & 30.1 & 28.7 \\
\hline Delinquent on payments & 6.2 & 8.6 & 0.0 & 19.9 & 22.9 & 100.0 & 28.4 & 21.4 \\
\hline Reached limit on credit cards & 15.3 & 21.1 & 0.0 & 49.1 & 51.3 & 69.9 & 100.0 & 44.2 \\
\hline Do not payoff balance & 24.0 & 33.1 & 0.0 & 77.2 & 85.2 & 82.8 & 69.5 & 100.0 \\
\hline \multicolumn{9}{|l|}{ Credit card(s) obtained: } \\
\hline Before beginning college & 36.4 & 49.5 & 53.8 & 43.8 & 41.7 & 35.4 & 43.5 & 40.9 \\
\hline First year of college & 26.4 & 35.9 & 32.3 & 40.7 & 44.2 & 50.1 & 42.2 & 42.7 \\
\hline After first year of college & 10.6 & 14.4 & 13.7 & 15.3 & 14.0 & 14.5 & 14.2 & 16.2 \\
\hline \multicolumn{9}{|l|}{ Credit card(s) acquired.: } \\
\hline Through a mail application & 25.1 & 34.4 & 30.4 & 39.8 & 47.1 & 39.4 & 39.8 & 40.9 \\
\hline At a bank/financial institution & 20.8 & 28.3 & 32.6 & 22.6 & 16.5 & 18.4 & 22.8 & 21.0 \\
\hline From parents & 10.7 & 14.7 & 19.1 & 8.7 & 3.5 & 3.9 & 7.0 & 7.7 \\
\hline Online & 5.5 & 7.6 & 6.9 & 8.5 & 8.5 & 6.7 & 8.9 & 8.3 \\
\hline At a campus table & 4.6 & 6.3 & 3.6 & 9.9 & 13.3 & 19.9 & 11.8 & 11.2 \\
\hline At a retail store & 2.8 & 3.8 & 3.1 & 4.8 & 4.1 & 5.8 & 4.6 & 5.2 \\
\hline Over the phone & 2.6 & 3.5 & 2.9 & 4.3 & 5.1 & 4.6 & 4.0 & 4.3 \\
\hline Other & 1.0 & 1.4 & 1.4 & 1.3 & 1.7 & 1.1 & 1.0 & 1.3 \\
\hline
\end{tabular}


Table 3 (conti.): Credit Characteristics of Students

\begin{tabular}{|c|c|c|c|c|c|c|c|c|}
\hline \multirow[b]{2}{*}{ Variable (mean/percentage) } & \multirow[b]{2}{*}{$\begin{array}{c}\text { All } \\
\text { Students } \\
(\mathrm{N}=\mathbf{2 6 , 8 9 6 )}\end{array}$} & \multirow[b]{2}{*}{$\begin{array}{c}\text { Students } \\
\text { w/ cc } \\
(\mathrm{N}=19,477)\end{array}$} & \multirow[b]{2}{*}{$\begin{array}{c}\text { Not at-risk } \\
\text { w/ cc } \\
(\mathrm{N}=11,124)\end{array}$} & \multirow[b]{2}{*}{$\begin{array}{c}\text { At-risk } \\
\text { w/cc } \\
(\mathrm{N}=8,353)\end{array}$} & \multicolumn{4}{|c|}{ Groups of At-Risk Students } \\
\hline & & & & & $\begin{array}{c}\text { Credit card } \\
\text { debt } \geq \$ 1000 \\
(\mathrm{~N}=4,233)\end{array}$ & $\begin{array}{c}\text { Delinquent } \\
\text { on payments } \\
(\mathrm{N}=1,666)\end{array}$ & $\begin{array}{c}\text { Reached } \\
\text { limit } \\
(\mathrm{N}=4,101)\end{array}$ & $\begin{array}{l}\text { Do not pay } \\
\text { balance in full } \\
(\mathrm{N}=6,445)\end{array}$ \\
\hline \multicolumn{9}{|l|}{ Financial aid } \\
\hline Receives financial aid & 71.7 & 70.4 & 65.3 & 77.2 & 80.5 & 81.3 & 76.7 & 81.3 \\
\hline Federal student loans & 48.2 & 48.8 & 38.3 & 62.8 & 68.8 & 70.3 & 63.4 & 69.2 \\
\hline Federal parent loans & 10.1 & 10.0 & 8.3 & 12.3 & 12.6 & 11.7 & 11.8 & 13.7 \\
\hline Alternative loans & 6.2 & 6.4 & 4.7 & 8.8 & 9.8 & 10.3 & 9.8 & 9.3 \\
\hline Federal work-study & 11.6 & 11.2 & 8.9 & 14.3 & 15.6 & 19.7 & 14.8 & 15.6 \\
\hline Need-based grants & 25.1 & 25.3 & 17.9 & 35.1 & 40.2 & 46.9 & 36.9 & 38.3 \\
\hline Scholarships & 38.3 & 36.3 & 41.4 & 29.5 & 27.8 & 25.5 & 28.6 & 27.8 \\
\hline Tuition waiver & 5.5 & 5.6 & 5.3 & 6.0 & 6.9 & 5.2 & 6.0 & 6.3 \\
\hline Financial aid $\geq \$ 10,000$ & 18.1 & 20.0 & 12.4 & 30.1 & 38.4 & 37.5 & 32.8 & 33.8 \\
\hline Financial aid not enough & 44.3 & 53.4 & 47.5 & 59.9 & 62.9 & 62.3 & 61.9 & 60.8 \\
\hline \multicolumn{9}{|l|}{ Other debt } \\
\hline Owes other debt & 28.9 & 28.6 & 18.4 & 42.2 & 49.5 & 54.6 & 46.9 & 45.5 \\
\hline Car loan & 11.3 & 13.1 & 7.7 & 20.3 & 27.9 & 20.3 & 21.0 & 22.4 \\
\hline Mortgage & 2.3 & 2.8 & 1.4 & 4.8 & 7.1 & 4.0 & 4.3 & 4.9 \\
\hline Informal loan (family/friends) & 8.2 & 7.7 & 6.0 & 9.9 & 10.6 & 14.6 & 12.0 & 10.2 \\
\hline Private loan from bank & 3.2 & 3.5 & 1.7 & 5.9 & 8.0 & 7.8 & 7.0 & 6.5 \\
\hline Installment loan & 1.9 & 2.2 & 0.6 & 4.3 & 6.5 & 5.0 & 5.1 & 4.8 \\
\hline Owes other debt $\geq \$ 1000$ & 16.0 & 16.9 & 1.0 & 26.2 & 34.8 & 31.3 & 29.3 & 28.5 \\
\hline
\end{tabular}


- $\quad$ Between $14.0 \%$ and $16.0 \%$ report balances over $\$ 1000$ and about $5.0 \%$ report balances over $\$ 3000$ (compared to $15.7 \%$ and $7.5 \%$, respectively, for Midwest students.)

- The majority obtains credit cards prior to college or during their freshman year (compared to $86.1 \%$ for Midwest students.)

Table 3 also shows that, in comparing the entire sample to those with credit cards, financially atrisk students were more likely to hold 4 or more credit cards and to owe more than $\$ 3000$ in credit card debt. Financially at-risk students were also much more likely to reach the borrowing limit on their credit cards, be delinquent on their payments, and/or be rejected for a credit card. They were less likely to be able to pay off their balances in full each month. These findings should not be surprising since many of these characteristics are being used to identify those at financial risk. (The credit practices of students for each campus can be found in Appendix $C$, Table 2C.)

\section{Credit Card Acquisition}

There has been growing concern among some campus administrators that the aggressive marketing of credit card companies on college campuses has substantially contributed to the recent rise in credit card debt among college students (i.e. The Education Resources Institute and The Institute for Higher Education Institution, 1998). A recent study by the U.S. General Accounting Office showed that $21-24 \%$ of students obtained credit cards by completing applications at campus tables. Another study conducted at Purdue University showed that $61 \%$ of students reported getting credit cards through campus vendors (Riggle, 2001). However, a recent study at the University of Illinois showed that only $15.7 \%$ of students with credit cards acquired them at a campus table (Lyons, 2004). Regardless, several colleges and universities in the Midwest and nationally have limited credit card solicitations on their campuses or have banned them altogether.

The students in this study were asked the following question, "How did you acquire the credit card you use the MOST?" Table 3 shows that completing applications received in the mail was the most popular way students acquired their cards - $34.4 \%$ of students with credit cards filled out applications they received in the mail. This is consistent with reports from the U.S. General Accounting Office which indicate that $36-37 \%$ of students acquire their cards by mail. Only $6.3 \%$ of students with credit cards reported that they acquired their card by completing an application at a campus table. 
Other ways Midwest students acquired their credit cards:

- $\quad 28.3 \%$ of students with a credit card obtained their cards through their financial institution.

- $\quad 14.7 \%$ acquired them through their parents.

- Less than $10 \%$ filled out applications over the phone or at a retail store $(3.5 \%$ and $3.8 \%$, respectively), and $7.6 \%$ acquired cards online.

It is interesting to note that financially at-risk students were more likely to have acquired their cards through a mail application or at a campus table. They were significantly less likely to have acquired their cards from their parents.

\section{Financial Aid}

Up until now, this report has focused primarily on students' credit card practices. We now investigate other types of debt held by students to develop a better understanding of the relationship between credit card debt, financial aid, and other types of borrowing.

Table 3 shows that, in general, $71.7 \%$ of students are utilizing some type of financial aid to fund their college education, where financial aid includes federal student loans, federal parent loans, alternative or private loans, federal work-study, need-based grants, scholarships, and/or tuition waivers. With respect to need-based assistance, $48.2 \%$ of the sample indicated that they had student loans, $10.1 \%$ had parent loans, $11.6 \%$ received federal work-study, and $25.1 \%$ received need-based grants. Approximately $18 \%$ of students had financial aid loans that totaled $\$ 10,000$ or more. Only $6.2 \%$ of the sample reported having alternative or private loans. However, a substantial fraction indicated that they were receiving scholarship funding (38.3\%).

Table 3 also shows that financial aid appears to play a key role in whether students are financially at-risk. Financially at-risk students with credit cards are more likely than those not at risk with credit cards to receive need-based assistance in the form of federal loans, federal workstudy, and/or need-based grants. They are less likely to receive scholarships.

Overall, these findings suggest that students with credit cards who are receiving financial aid are more likely than those with credit cards to be at greater financial risk when they have to pay off their debts after graduation. As we will see in the next section, these students are also more likely to hold large amounts of other debt (i.e. car loan, mortgage) suggesting that financially atrisk students are borrowing more in general. 
There has been growing concern that student financial aid is no longer enough to cover the rising costs of higher education. A substantially large number of students $(44.3 \%)$ reported charging school items (i.e. textbooks, tuition, fees) to their credit card(s), because financial aid was not enough to cover the cost. In addition, financially at-risk students were more likely than the sample in general to report charging school related items to their cards (about $60.0 \%$ ). It is unclear, though, what items students may have classified as "school items." Regardless, the finding seems to suggest that financial aid amounts may not be enough to cover educational costs, especially for those students most at risk. However, it may be the case that financially atrisk students are less aware of their financial aid options and not fully utilizing the system. (See Appendix $C$, Table 2C for financial aid statistics for each campus.)

\section{Other Types of Borrowing}

Besides credit card debt and financial aid loans, some students incur other types of debt. As Table 3 shows, students who reported owing other debt indicated that they had car loans, mortgage debt, installment loans, informal loans from family/friends, and/or private loans from a financial institution. In general, $28.9 \%$ of students indicated that they owed some type of other debt primarily in the form of car loans or informal loans from family/friends, and $16.0 \%$ owed $\$ 10,000$ or more in other debt. Given the previous findings, it is not surprising that financially at-risk students with credit cards were significantly more likely than the student sample to borrow other types of debt and to owe $\$ 10,000$ more in other debt.

- $\quad 42.2 \%$ of financially at-risk students with credit cards owed some type of other debt compared to $28.9 \%$ of all students and $18.4 \%$ of students with credit cards who were not at risk.

- $\quad 26.2 \%$ of financially at-risk students with credit cards owed $\$ 1000$ or more in other debt compared to $16.0 \%$ of all students and $1.0 \%$ of students with credit cards who were not at risk.

These findings coupled with the financial aid statistics again raise concerns that financially atrisk students are likely borrowing more in general to finance their college education. 


\section{Financial Education Needs of Students}

In addition to asking students about their credit practices, student leaders were also asked a series of questions about their financial education needs. The questions included, but were not limited to, the following:

1. If you were in need of personal finance information, how would you MOST like to receive this information?

2. Who would you MOST like to receive this information from?

3. In the last few years, where have you gone to find financial information?

4. Would you register for a classroom course related to personal finance if offered on campus?

5. Would you register if the course was offered online?

\section{Preferences for the Delivery of Financial Information}

The first three questions focus on how students prefer to receive financial information. For these questions, students were given several options and asked to select their top three choices. Table 4 summarizes the responses for the entire sample and those at risk. With respect to how they would like to receive financial information, students ranked receiving information in a one-onone discussion with a financial professional as their first choice $(51.9 \%)$, on the Internet as their second choice $(47.7 \%)$, and in a packet of printed materials as their third choice $(40.8 \%)$. These delivery methods were preferred over receiving information in a campus workshop/seminar or in a formal college course. These preferences did not vary by financial risk. These findings were fairly consistent across campuses (See Appendix $C$, Table $3 C$ for preferences by campus).

With respect to who they would like to receive financial information from, students indicated that they preferred to receive this information from financial experts/professionals (58.2\%), their parents (49.8\%), and financial aid counselors (44.7\%). Only 18.3\% of students expressed an interest in receiving information from other students/peers. This is a particularly interesting finding given that a number of campuses are now using peers to offer financial education workshops and/or financial counseling to students. Receiving financial information from professors and obtaining information on their own were least preferred by the students. Interestingly, students with credit cards who were financially at-risk were significantly less likely than students without credit cards who were not at risk to prefer receiving information from their parents and more likely to prefer receiving information from financial aid counselors and on their own.

With respect to where students are currently going to find useful information on credit, the number one response was that they ask their parents $(73.5 \%)$. Other top sources for credit 
Table 4: Preferences for the Delivery of Financial Information

\begin{tabular}{|c|c|c|c|c|c|c|c|c|}
\hline \multirow[b]{2}{*}{ Variable (mean/percentage) } & \multirow[b]{2}{*}{$\begin{array}{c}\text { All } \\
\text { Students } \\
(\mathrm{N}=\mathbf{2 6 , 8 9 6 )}\end{array}$} & \multirow[b]{2}{*}{$\begin{array}{c}\text { Students } \\
\text { w/ cc } \\
(\mathrm{N}=19,477)\end{array}$} & \multirow[b]{2}{*}{$\begin{array}{c}\text { Not at-risk } \\
\text { w/ cc } \\
(\mathrm{N}=11,124)\end{array}$} & \multirow[b]{2}{*}{$\begin{array}{c}\text { At-risk } \\
\text { w/cc } \\
(\mathrm{N}=8,353)\end{array}$} & \multicolumn{4}{|c|}{ Groups of At-Risk Students } \\
\hline & & & & & $\begin{array}{c}\text { Credit card } \\
\text { debt } \geq \$ 1000 \\
(\mathrm{~N}=4,233)\end{array}$ & $\begin{array}{c}\text { Delinquent } \\
\text { on payments } \\
(\mathrm{N}=1,666)\end{array}$ & $\begin{array}{c}\text { Reached } \\
\text { limit } \\
(\mathrm{N}=4,101)\end{array}$ & $\begin{array}{r}\text { Do not p } \\
\text { balance in } \\
(\mathrm{N}=6,44\end{array}$ \\
\hline \multicolumn{9}{|c|}{ How you like to receive financial information? } \\
\hline One-on-one discussion & 51.9 & 51.1 & 51.1 & 51.1 & 51.9 & 50.4 & 49.7 & 50.7 \\
\hline On the Internet & 47.7 & 47.2 & 47.2 & 47.3 & 48.0 & 44.8 & 48.0 & 47.0 \\
\hline Campus workshop/seminar & 21.6 & 21.0 & 20.7 & 21.4 & 21.2 & 24.0 & 21.6 & 20.9 \\
\hline Formal college course & 12.4 & 13.1 & 12.6 & 13.8 & 14.8 & 14.8 & 14.7 & 13.2 \\
\hline \multicolumn{9}{|l|}{ Who you like to receive information from? } \\
\hline Financial experts/professionals & 58.2 & 59.0 & 57.6 & 60.9 & 64.6 & 62.0 & 61.0 & 61.4 \\
\hline Parents & 49.8 & 48.8 & 56.6 & 38.5 & 30.7 & 29.2 & 36.3 & 36.4 \\
\hline Financial aid counselors & 44.7 & 42.0 & 40.4 & 44.1 & 43.8 & 48.0 & 44.2 & 44.9 \\
\hline Other students/peers & 18.3 & 17.2 & 16.7 & 17.8 & 16.5 & 20.4 & 18.7 & 17.2 \\
\hline Obtain information on my own & 16.5 & 17.5 & 16.2 & 19.1 & 21.3 & 18.2 & 19.9 & 19.2 \\
\hline \multicolumn{9}{|c|}{ Where you have found useful information? } \\
\hline Parents & 73.5 & 72.4 & 81.1 & 60.8 & 50.2 & 50.9 & 57.7 & 58.9 \\
\hline Friends & 21.7 & 20.8 & 18.0 & 24.4 & 24.4 & 28.0 & 25.6 & 24.2 \\
\hline Financial institutions & 18.0 & 19.8 & 18.7 & 21.1 & 23.2 & 18.3 & 20.9 & 21.2 \\
\hline Internet & 14.3 & 15.0 & 12.1 & 18.8 & 21.6 & 22.1 & 19.8 & 18.9 \\
\hline High school or college course & 11.8 & 11.0 & 11.9 & 9.8 & 8.7 & 7.9 & 9.2 & 9.5 \\
\hline Books, magazines, and newspapers & 10.0 & 10.2 & 8.3 & 12.6 & 15.4 & 14.4 & 13.2 & 13.0 \\
\hline TV and radio & 4.4 & 4.3 & 3.4 & 5.6 & 6.2 & 8.4 & 5.9 & 5.8 \\
\hline Non-profit organizations & 3.4 & 3.4 & 2.2 & 5.1 & 6.9 & 9.4 & 6.3 & 5.5 \\
\hline Have not gone to find information & 10.2 & 9.5 & 7.7 & 11.9 & 14.7 & 13.1 & 12.9 & 12.5 \\
\hline
\end{tabular}

Note: "Students w/ cc" represents students holding at least one credit card; "Not at-risk w/ cc" identifies students with a credit card but no at-risk behaviors; "Atrisk w/ cc" identifies students with a credit card and at least one at-risk behavior. The remaining columns classify students by at-risk behaviors and are not conditional on holding a credit card. Percentages do not sum to 100 percent for each category because students could select more than one category. 
information included friends (21.7\%), financial institutions (18.0), and the Internet (14.3\%). Financially at-risk students were least likely to seek out information from their parents and more likely to consult friends, the Internet, and books, magazines, and newspapers. Interestingly, $11.9 \%$ of students with credit cards who were financially at-risk indicated that they had not gone to find information compared to $7.7 \%$ of students with credit cards who were not at risk. This finding suggests that those who most need the information either are not seeking it out or do not know where to go for useful information, or are not aware of available sources for information.

\section{Knowledge and Preferences for Specific Financial Topics}

In addition to the previous three questions, students were also asked about "how important" and "how well" they understood the following six financial topics:

- $\quad$ Personal finance and budgeting

- $\quad$ Credit cards and terms

- $\quad$ Shopping for a car loan

- $\quad$ Financing a college education

- $\quad$ Saving and investing

- $\quad$ Planning for retirement.

Students were asked to rank their level of importance and understanding of each topic on a scale of 1 to 5 with 1 being "very important" or "complete understanding" and 5 being "not important" or "no understanding." If a student ranked a topic with a "1" or a " 2, ," then the student was classified as ranking the topic as important or they had a general or better understanding of the topic. Table 5 presents the findings in terms of the percentage of students who thought the topic was important and the percentage of students who indicated that they understood the topic. (The findings by campus can be found in Appendix C, Table 4C).

With respect to level of importance, students in general felt that the topics of "personal finance and budgeting," "saving and investing," and "financing a college education" were more important than "credit cards and terms," "shopping for a car loan," and "planning for retirement." However, financially at-risk students ranked the topic of "credit cards and terms" as more important than students not at risk. $74.2 \%$ of students with credit cards who were financially at-risk believed that the topic of "credit cards and terms" was important compared to $64.4 \%$ of those not at risk.

With respect to level of understanding, students tended to rank their level of understanding of a particular topic lower than how important they ranked the topic. For example, $87.0 \%$ of the sample indicated that they believed the topic of "personal finance and budgeting" was important; however, only $59.5 \%$ felt that they had an understanding of the topic. The pattern of disparity between the level of importance and the level of understanding was similar across topics. The 
Table 5: Knowledge and Preferences for Financial Education Topics

\begin{tabular}{|c|c|c|c|c|c|c|c|c|}
\hline \multirow[b]{2}{*}{ Variable (mean/percentage) } & \multirow[b]{2}{*}{$\begin{array}{c}\text { All } \\
\text { Students } \\
(\mathbf{N = 2 6 , 8 9 6 )}\end{array}$} & \multirow[b]{2}{*}{$\begin{array}{c}\text { Students } \\
\text { w/ cc } \\
(\mathrm{N}=19,477)\end{array}$} & \multirow[b]{2}{*}{$\begin{array}{c}\text { Not at-risk } \\
\text { w/ cc } \\
(\mathrm{N}=11,124)\end{array}$} & \multirow[b]{2}{*}{$\begin{array}{c}\text { At-risk } \\
\text { w/cc } \\
(\mathrm{N}=8,353)\end{array}$} & \multicolumn{4}{|c|}{ Groups of At-Risk Students } \\
\hline & & & & & $\begin{array}{c}\text { Credit card } \\
\text { debt } \geq \$ 1000 \\
(\mathrm{~N}=4,233)\end{array}$ & $\begin{array}{c}\text { Delinquent } \\
\text { on payments } \\
(\mathrm{N}=1,666)\end{array}$ & $\begin{array}{c}\text { Reached } \\
\text { limit } \\
(\mathrm{N}=4,101)\end{array}$ & $\begin{array}{l}\text { Do not pay } \\
\text { balance in full } \\
(\mathrm{N}=6,445)\end{array}$ \\
\hline \multicolumn{9}{|l|}{ Financial topic is important } \\
\hline Personal finance and budgeting & 87.0 & 87.3 & 87.7 & 86.7 & 87.5 & 85.5 & 85.9 & 86.7 \\
\hline Credit cards and terms & 59.1 & 68.6 & 64.4 & 74.2 & 78.3 & 69.9 & 73.8 & 74.7 \\
\hline Shopping for a car loan & 33.2 & 35.5 & 31.6 & 40.6 & 45.9 & 41.2 & 40.7 & 42.0 \\
\hline Financing a college education & 77.6 & 75.6 & 73.7 & 78.3 & 79.4 & 82.3 & 77.5 & 80.3 \\
\hline Saving and investing & 83.4 & 82.9 & 86.3 & 78.4 & 77.2 & 75.6 & 76.9 & 77.1 \\
\hline Planning for retirement & 42.7 & 43.8 & 43.5 & 44.2 & 48.1 & 45.6 & 43.9 & 43.6 \\
\hline \multicolumn{9}{|l|}{ Understand the financial topic } \\
\hline Personal finance and budgeting & 59.5 & 62.2 & 65.1 & 58.4 & 59.6 & 48.7 & 55.4 & 56.5 \\
\hline Credit cards and terms & 51.9 & 60.7 & 60.2 & 61.3 & 65.2 & 54.0 & 59.6 & 60.4 \\
\hline Shopping for a car loan & 21.6 & 24.0 & 20.2 & 29.0 & 34.2 & 26.5 & 28.8 & 29.3 \\
\hline Financing a college education & 48.3 & 48.6 & 48.4 & 48.8 & 51.3 & 49.2 & 48.1 & 49.6 \\
\hline Saving and investing & 51.8 & 52.1 & 56.0 & 47.0 & 45.5 & 38.8 & 44.7 & 45.1 \\
\hline Planning for retirement & 19.0 & 20.4 & 20.2 & 20.6 & 23.2 & 19.0 & 20.7 & 19.4 \\
\hline
\end{tabular}


one exception was for the topic of credit. While only $59.1 \%$ indicated that they thought "credit cards and terms" was important, only $51.9 \%$ believed they had an understanding of the topic.

Interestingly, $74.2 \%$ of financially at-risk students indicated that they believed the topic of "credit cards and terms" was important, while $61.3 \%$ felt they understood the topic. This finding suggests that financially at-risk students may be less likely than those not at risk to see a need for credit education and be less open to receiving financial education related to credit. Those not at risk may more readily see that they have a need for financial education related to credit card usage, perhaps this has contributed to why they have not yet misused or mismanaged their credit cards.

\section{Preferences for Financial Education Courses}

With respect to formal financial education, students were asked if they had taken any courses in high school or were currently taking any college courses related to personal finance. Table 6 shows that $27.2 \%$ of students indicated that they had or were taking a personal finance course. Students who had taken a personal finance course were somewhat less likely to be financially atrisk. (For the findings by campus, see Appendix C, Table 5C.)

Students were also asked about whether they would register for a course related to personal finance. The majority of the sample $(72.1 \%)$ indicated that they would register for a classroom course on personal finance if offered on their campus. However, 27.9\% reported that they would only register for the course if it was free to students, and $32.4 \%$ would only register if it was offered for course credit. Only $11.5 \%$ of the students would register for the course regardless of the cost or credit they received.

Would they register for the course if it was offered online? Students reported that they preferred a classroom course over an online course. $34.0 \%$ of students would not register for an online course compared to $27.9 \%$ of students who would not register for a classroom course. Students were more likely to indicate that they would register for the online course if it was free. Interestingly, financially at-risk students indicated that they would be more likely than students not at risk to register for a course on personal finance. They also preferred the classroom to the online course. These findings suggest that students may prefer personal attention and small group settings when receiving financial information. 
Table 6: Preferences for Personal Finance Courses

\begin{tabular}{|c|c|c|c|c|c|c|c|c|}
\hline \multirow[b]{2}{*}{ Variable (mean/percentage) } & \multirow[b]{2}{*}{$\begin{array}{c}\text { All } \\
\text { Students } \\
\text { (N=26,896) }\end{array}$} & \multirow[b]{2}{*}{$\begin{array}{c}\text { Students } \\
\text { w/ cc } \\
(\mathrm{N}=19,477)\end{array}$} & \multirow[b]{2}{*}{$\begin{array}{c}\text { Not at-risk } \\
\mathrm{w} / \mathrm{cc} \\
(\mathrm{N}=11,124)\end{array}$} & \multirow[b]{2}{*}{$\begin{array}{c}\text { At-risk } \\
\mathrm{w} / \mathrm{cc} \\
(\mathrm{N}=8,353)\end{array}$} & \multicolumn{4}{|c|}{ Groups of At-Risk Students } \\
\hline & & & & & $\begin{array}{c}\text { Credit card } \\
\text { debt } \geq \$ 1000 \\
(\mathrm{~N}=4,233)\end{array}$ & $\begin{array}{c}\text { Delinquent } \\
\text { on payments } \\
(\mathrm{N}=1,666)\end{array}$ & $\begin{array}{c}\text { Reached } \\
\text { limit } \\
(\mathrm{N}=4,101)\end{array}$ & $\begin{array}{c}\text { Do not pay } \\
\text { balance in full } \\
(\mathrm{N}=6,445)\end{array}$ \\
\hline Took a personal finance course & 27.2 & 27.9 & 29.5 & 25.8 & 25.2 & 22.9 & 24.5 & 25.1 \\
\hline \multicolumn{9}{|l|}{ Would you register for course? } \\
\hline Yes, only if class was free & 27.9 & 28.2 & 25.6 & 31.5 & 33.2 & 36.6 & 32.4 & 32.4 \\
\hline Yes, only if for course credit & 32.4 & 32.0 & 32.2 & 31.6 & 29.6 & 29.2 & 31.6 & 31.5 \\
\hline Yes, regardless of cost or credit & 11.5 & 12.1 & 11.6 & 12.7 & 14.4 & 14.0 & 13.0 & 12.4 \\
\hline No & 27.9 & 27.6 & 30.4 & 23.9 & 22.6 & 20.0 & 22.9 & 23.5 \\
\hline \multicolumn{9}{|l|}{ Would you register for online course? } \\
\hline Yes, only if class was free & 33.6 & 33.9 & 31.7 & 36.9 & 38.8 & 39.9 & 38.7 & 37.7 \\
\hline Yes, only if for course credit & 22.4 & 22.2 & 22.2 & 22.1 & 20.5 & 20.9 & 22.4 & 21.6 \\
\hline Yes, regardless of cost or credit & 9.8 & 10.4 & 9.4 & 11.7 & 13.8 & 12.8 & 11.7 & 12.0 \\
\hline No & 34.0 & 33.3 & 36.6 & 29.0 & 26.6 & 26.2 & 27.0 & 28.5 \\
\hline
\end{tabular}




\section{The Consequences of Financial Strain on College Campuses}

As mentioned earlier in this report, a number of students on college campuses are experiencing financial strain. College costs have been rising at record levels, and students have had to borrow more to finance their education. The financial burden that students are facing leads one to question the impact that financial strain is having on college campuses. To identify how financial burden may be affecting students' academically, the following survey questions were asked:

1. How likely is it that your financial situation will make it difficult to complete your college degree?

2. Have you ever reduced the number of credit hours you were taking so that you could work more hours to pay your expenses?

3. Have you ever dropped out for a semester so that you could work more hours to pay your expenses?

Table 7 shows that almost 1 in 3 students reported that their financial situation was "likely" or "somewhat likely" to affect their ability to complete their college degree. Almost 16.0\% reported that they reduced the number of credit hours they were taking and 5.6\% said they dropped out for a semester. Financially at-risk students, especially those who had been delinquent on their credit card payments, were more likely than those not at risk to indicate that their financial situation was affecting their ability to complete their degree. Over $27.0 \%$ of financially at-risk students reported that they had reduced the number of credit hours they were taking and $12.0 \%$ had dropped out for a semester compared to $10.1 \%$ and $2.1 \%$ of students not at risk, respectively.

Students were also asked two additional questions to assess how financial strain was affecting other aspects of their lives:

4. Does your financial situation affect your ability to concentrate on your studies?

5. Do you find yourself losing sleep or experiencing physical discomfort because of your financial situation?

Table 7 reveals that 1 in 3 students had difficulty concentrating on their studies and $26.9 \%$ were experiencing physical or mental discomfort because of their financial situation. Students who were mismanaging or misusing their credit cards were significantly more likely than other students to report physical or mental discomfort. Almost $50.0 \%$ of financially at-risk students reported having difficulty concentrating on their studies compared to $23.9 \%$ of non at-risk students. Over $41.0 \%$ of those at risk also indicated that they were losing sleep or experiencing 


\section{Table 7: The Consequences of Student Financial Strain}

\begin{tabular}{|c|c|c|c|c|c|c|c|c|}
\hline \multirow[b]{2}{*}{ Variable (mean/percentage) } & \multirow[b]{2}{*}{$\begin{array}{c}\text { All } \\
\text { Students } \\
(\mathbf{N}=\mathbf{2 6 , 8 9 6 )}\end{array}$} & \multirow[b]{2}{*}{$\begin{array}{c}\text { Students } \\
\text { w/ cc } \\
(\mathrm{N}=19,477)\end{array}$} & \multirow[b]{2}{*}{$\begin{array}{c}\text { Not at-risk } \\
\text { w/ cc } \\
(\mathrm{N}=11,124)(\end{array}$} & \multirow[b]{2}{*}{$\begin{array}{c}\text { At-risk } \\
\text { w/cc } \\
(\mathrm{N}=8,353)\end{array}$} & \multicolumn{4}{|c|}{ Groups of At-Risk Students } \\
\hline & & & & & $\begin{array}{c}\text { Credit card } \\
\text { debt } \geq \$ 1000 \\
(N=4,233)\end{array}$ & $\begin{array}{c}\text { Delinquent } \\
\text { on payments } \\
(\mathrm{N}=1,666)\end{array}$ & $\begin{array}{c}\text { Reached } \\
\text { limit } \\
(\mathrm{N}=4,101)\end{array}$ & $\begin{array}{l}\text { Do not pay } \\
\text { balance in full } \\
(\mathrm{N}=6,445)\end{array}$ \\
\hline \multicolumn{9}{|l|}{$\begin{array}{l}\text { Likelihood financial situation will } \\
\text { affect completion of college dearee.... }\end{array}$} \\
\hline Likely & 12.4 & 11.8 & 8.6 & 16.0 & 17.3 & 23.5 & 18.8 & 16.8 \\
\hline Somewhat likely & 18.0 & 16.8 & 14.2 & 20.4 & 21.3 & 25.0 & 21.8 & 21.5 \\
\hline Not likely & 69.5 & 71.3 & 77.2 & 63.4 & 61.3 & 51.4 & 59.2 & 61.6 \\
\hline \multicolumn{9}{|l|}{ As a result of financial situation.... } \\
\hline Reduced number of credit hours & 15.9 & 17.5 & 10.1 & 27.2 & 34.4 & 38.8 & 30.8 & 29.6 \\
\hline Dropped out for a semester & 5.6 & 6.4 & 2.1 & 12.0 & 17.3 & 21.7 & 15.2 & 13.4 \\
\hline Difficulty concentrating on studies & 33.2 & 34.5 & 23.9 & 48.6 & 56.3 & 66.9 & 54.1 & 52.4 \\
\hline Losing sleep/physical discomfort & 26.9 & 28.2 & 18.4 & 41.3 & 49.4 & 61.6 & 48.1 & 45.6 \\
\hline
\end{tabular}

Note: "Students w/ cc" represents students holding at least one credit card; "Not at-risk w/ cc" identifies students with a credit card but no at-risk behaviors; "Atrisk w/ cc" identifies students with a credit card and at least one at-risk behavior. The remaining columns classify students by at-risk behaviors and are not conditional on holding a credit card. 
physical discomfort compared to only $18.4 \%$ of students not at risk. Those who had been delinquent on their credit card payments and who were carrying large credit card balances were most likely to be affected.

These findings have important implications for campus administrators. It is clear from these findings that financial strain is likely affecting other aspects of students' everyday lives. A precarious financial situation may lead to financial stress which may in turn affect a student's physical and/or mental health. Poor health may then affect a student's capacity to accumulate human capital and assets which adds to his/her financial burden and affects his/her overall quality of life. For some students, the end result may be that they are unable to complete their degree.

\section{A Profile of Financially At-Risk Students}

\section{The Model}

Up until this point, this report has been primarily descriptive. For those who may be interested, regression analysis is now conducted to gain a better understanding of the specific degree to which various factors affect the likelihood a student is financially at-risk. Probit models are estimated for each of the four at-risk behaviors: 1) credit card balances of $\$ 1000$ or more, 2) delinquent on their credit card payments by two months or more, 3) have reached the limit on their credit cards, and 4) only pay off their credit card balances some of the time or never. For the first at-risk behavior, the relationship is assumed to be as follows:

$$
D_{i}^{*}=X_{i}^{\prime} \beta_{1}+u_{i} \text {, where } D_{i}=1 \text { iff } D_{i}^{*} \geq 1000 \text { and } 0 \text { otherwise for } i=\{1, \ldots, I\} \text {. }
$$

$D_{i}$ is the discrete dependent variable that is equal to one if the $i^{\text {th }}$ student holds credit card balances of $\$ 1000$ or more and zero otherwise. $D_{i}$ is determined by the continuous, latent variable $D_{i}^{*}$, the actual amount of credit card debt held by the student.

The factors that determine $D_{i}{ }^{*}$, and thus $D_{i}$, are represented by the vector $X_{i}$. Included in $X_{i}$ are factors that account for students' financial characteristics such as their monthly income, whether they are financially independent, whether they receive financial aid, whether they have $\$ 1000$ or more in other debt such as a car loan, mortgage, or other private loan, when they obtained their first credit card, and how they acquired the credit card they use the most. The vector $X_{i}$ also controls for student demographics such as year in school, gender, ethnicity, marital status, grade point average, residential status, whether they are a first-generation college student, whether they rent an apartment, whether their parents own their own home, and the population of their home town. Information on their level of financial knowledge and the likelihood that their financial situation will affect their ability to complete their college degree is also included. It is important 
to note that some of these factors may be endogenous and dependent on other factors included in the model. Due to data limitations, it is not feasible to construct instruments to control for the possibility of endogeneity. Therefore, it is assumed that these values have been exogenously determined.

The error terms, $\mathrm{u}_{\mathrm{i}}$, are assumed to be distributed standard normally with mean zero and variance $\sigma_{\mathrm{i}}$ equal to one. The probit method is used to estimate the model and obtain consistent estimates of the regressors. The probit method is also used to identify the factors that determine the probability that a student is 1) delinquent on their credit card payments by two months or more, 2 ) reaches the limit on their credit cards, and 3) only pays off their credit card balances some of the time or never. In all three cases, the likelihood functions for each of the probit models are estimated and consistent estimates of the regressors are obtained.

The results from the four probit models are presented in Table 8. Since researchers may be concerned that differences in the behavior and characteristics of those without credit cards and those with credit cards may exist among those who are not financially at-risk, the models are estimated for only those students who reported having a credit card. For each table, the marginal effects have been estimated at the mean values.

\section{Probability of Having Credit Card Balances $\geq \$ 1000$}

As Table 8 shows, students who receive more in financial aid, hold more in other debt, and are financially independent from their parents are significantly more likely to hold $\$ 1000$ or more in credit card debt. Specifically, having $\$ 10,000$ or more in financial aid increases a student's probability of owing $\$ 1000$ or more in credit card debt by 11.0 percentage points while holding some type of other debt greater than or equal to $\$ 1000$ increases a student's probability by 9.8 percentage points. Being financially independent increases the probability by 7.7 percentage points.

Students who acquired the credit card they use the most from a source other than their parents are also significantly more likely to have credit card balances of $\$ 1000$ or more. Those who acquired their credit card at a campus table or over the phone are most at risk. In particular, students who acquired their credit card at a campus table are 26.1 percentage points more likely to be at risk than those who acquired their card from their parents. Those who acquired a card over the phone are 24.3 percentage points more likely. Also, those who acquired cards before college or during their first year at college are more likely to be at risk than those who acquired them after their first year of college.

Other factors that significantly increase a student's probability of holding $\$ 1000$ or more in credit card debt include being older, female, black, Hispanic, married, renting an apartment, and being a first-generation college student. Interestingly, students who come from home towns that are located in rural areas with populations of less than 2,500 are more likely to be at risk. Those 
Table 8: Probability Student Is Financially At-Risk (students with credit cards)

\begin{tabular}{|c|c|c|c|c|}
\hline \multirow[b]{2}{*}{ Variable } & \multicolumn{2}{|c|}{ Credit card debt $\geq \$ 1000$} & \multicolumn{2}{|c|}{ Delinquent on payments } \\
\hline & $\mathrm{ME}$ & SE & ME & SE \\
\hline Financial aid $\geq \$ 10,000$ & 0.1100 & $(0.0080)^{* *}$ & 0.0251 & $(0.0043)^{* *}$ \\
\hline Other debt $\geq \$ 1000$ & 0.0980 & $(0.0087)^{* *}$ & 0.0252 & $(0.0048)^{* *}$ \\
\hline Financially Independent & 0.0769 & $(0.0082)^{* *}$ & 0.0243 & $(0.0046)^{* *}$ \\
\hline Acquired card in mail & 0.1619 & $(0.0129)^{* *}$ & 0.0469 & $(0.0080)^{* *}$ \\
\hline Acquired card at bank & 0.0341 & $(0.0124)^{* *}$ & 0.0279 & $(0.0080)^{* *}$ \\
\hline Acquired card at online & 0.1623 & $(0.0201)^{* *}$ & 0.0423 & $(0.0123)^{* *}$ \\
\hline Acquired card at campus table & 0.2611 & $(0.0224)^{* *}$ & 0.1450 & $(0.0186) * *$ \\
\hline Acquired card at retail store & 0.1102 & $(0.0234)^{* *}$ & 0.0733 & $(0.0171)^{* *}$ \\
\hline Acquired card at phone & 0.2431 & $(0.0267)^{* *}$ & 0.0671 & $(0.0170) * *$ \\
\hline Acquired card other & 0.1459 & $(0.0348)^{* *}$ & 0.0318 & $(0.0213)^{*}$ \\
\hline Obtained card before college & 0.0823 & $(0.0083)^{* *}$ & 0.0090 & $(0.0047)^{*}$ \\
\hline Obtained card first year in college & 0.0848 & $(0.0090)^{* *}$ & 0.0194 & $(0.0050)^{* *}$ \\
\hline Freshman & -0.1523 & $(0.0057)^{* *}$ & -0.0405 & $(0.0038)^{* *}$ \\
\hline Sophomore & -0.1070 & $(0.0059)^{* *}$ & -0.0281 & $(0.0037) * *$ \\
\hline Junior & -0.0409 & $(0.0059)^{* *}$ & -0.0114 & $(0.0034) * *$ \\
\hline Female & 0.0224 & $(0.0056)^{* *}$ & 0.0146 & $(0.0031)^{* *}$ \\
\hline Black & 0.1390 & $(0.0182)^{* *}$ & 0.1112 & $(0.0130)^{* *}$ \\
\hline Asian & 0.0107 & $(0.0113)$ & 0.0193 & $(0.0074) * *$ \\
\hline Hispanic & 0.0892 & $(0.0168)^{* *}$ & 0.0423 & $(0.0101)^{* *}$ \\
\hline Married & 0.0883 & $(0.0166)^{* *}$ & -0.0035 & $(0.0064)$ \\
\hline GPA (3.0-3.5) & 0.0463 & $(0.0072)^{* *}$ & 0.0264 & $(0.0046)^{* *}$ \\
\hline GPA (2.0-2.9) & 0.1345 & $(0.0095)^{* *}$ & 0.0848 & $(0.0070)^{* *}$ \\
\hline GPA $(<2.0)$ & 0.2265 & $(0.0401)^{* *}$ & 0.1916 & $(0.0325)^{* *}$ \\
\hline Out-of-state resident & -0.0176 & $(0.0093)^{*}$ & -0.0085 & $(0.0052)$ \\
\hline International student & 0.0268 & $(0.0212)$ & 0.0017 & $(0.0104)$ \\
\hline $1^{\text {st }}$ generation college student & 0.0229 & $(0.0066)^{* *}$ & 0.0047 & $(0.0035)$ \\
\hline Rents an apartment & 0.0319 & $(0.0063)^{* *}$ & 0.0127 & $(0.0035)^{* *}$ \\
\hline Parents own home & -0.0358 & $(0.0095)^{* *}$ & -0.0242 & $(0.0056)^{* *}$ \\
\hline Income/month (\$1-\$249) & -0.0022 & $(0.0080)$ & -0.0036 & $(0.0043)$ \\
\hline Income/month $(\$ 250-\$ 499)$ & 0.0374 & $(0.0081)^{* *}$ & 0.0007 & $(0.0042)$ \\
\hline Income/month $(\$ 500-\$ 749)$ & 0.0920 & $(0.0118)^{* *}$ & -0.0025 & $(0.0053)$ \\
\hline Income/month(\$750-\$999) & 0.0961 & $(0.0169)^{* *}$ & -0.0090 & $(0.0063)$ \\
\hline Income/month $(\geq \$ 1,000)$ & 0.1585 & $(0.0169)^{* *}$ & -0.0000 & $(0.0067)$ \\
\hline Town/city (pop 2,500-20,000) & -0.0444 & $(0.0084)^{* *}$ & -0.0171 & $(0.0046)^{* *}$ \\
\hline City (pop 20,000-99,999) & -0.0172 & $(0.0075)^{* *}$ & -0.0119 & $(0.0039)^{* *}$ \\
\hline City (pop 100,000 or more) & -0.0195 & $(0.0072)^{* *}$ & -0.0138 & $(0.0039)^{* *}$ \\
\hline Has taken personal finance course & -0.0158 & $(0.0059)^{* *}$ & -0.0104 & $(0.0033)^{* *}$ \\
\hline Finances likely to affect degree & 0.0388 & $(0.0095)^{* *}$ & 0.0420 & $(0.0062)^{* *}$ \\
\hline Finances somewhat likely to affect degree & 0.0446 & $(0.0082)^{* *}$ & 0.0327 & $(0.0051)^{* *}$ \\
\hline Observations & & 19,477 & & 19,477 \\
\hline $\mathrm{R}^{2}$ & & 0.2607 & & 0.1944 \\
\hline
\end{tabular}

Note: ME represents the marginal effects for the probit model. Standard errors for the marginal effects are indicated by $(\cdot)$. The symbols $(* *)$ and $(*)$ indicate statistical significance at the 5.0 and 10.0 percent levels, respectively. Omitted categories include: senior, white, GPA (3.6-4.0), in-state resident, not working, rural area (pop $<2,500$ ), obtained credit card after first year of college, acquired card from parents, and finances not likely to affect degree. Campus dummies have been included in the model to control for individual campus effects. 
Table 8 (conti.): Probability Student Is Financially At-Risk (students with credit cards)

\begin{tabular}{|c|c|c|c|c|}
\hline \multirow[b]{2}{*}{$\underline{\text { Variable }}$} & \multicolumn{2}{|c|}{ Reached limit on credit cards } & \multicolumn{2}{|c|}{ Does not pay balance in full } \\
\hline & ME & SE & ME & SE \\
\hline Financial aid $\geq \$ 10,000$ & 0.0947 & $(0.0081)^{* *}$ & 0.1759 & $(0.0099)^{* *}$ \\
\hline Other debt $\geq \$ 1000$ & 0.0955 & $(0.0090)^{* *}$ & 0.1348 & $(0.0108)^{* *}$ \\
\hline Financially Independent & 0.0640 & $(0.0084)^{* *}$ & 0.0610 & $(0.0103)^{* *}$ \\
\hline Acquired card in mail & 0.0893 & $(0.0113)^{* *}$ & 0.0860 & $(0.0127)^{* *}$ \\
\hline Acquired card at bank & 0.0429 & $(0.0113)^{* *}$ & -0.0054 & $(0.0128)^{* *}$ \\
\hline Acquired card at online & 0.1148 & $(0.0173)^{* *}$ & 0.0892 & $(0.0182)^{* *}$ \\
\hline Acquired card at campus table & 0.1713 & $(0.0191)^{* *}$ & 0.1795 & $(0.0204)^{* *}$ \\
\hline Acquired card at retail store & 0.0840 & $(0.0204)^{* *}$ & 0.0991 & $(0.0229) * *$ \\
\hline Acquired card at phone & 0.0915 & $(0.0215)^{* *}$ & 0.0993 & $(0.0234)^{* *}$ \\
\hline Acquired card other & -0.0116 & $(0.0271)$ & 0.0070 & $(0.0322)$ \\
\hline Obtained card before college & 0.0354 & $(0.0089)^{* *}$ & 0.0059 & $(0.0109)^{* *}$ \\
\hline Obtained card first year in college & 0.0395 & $(0.0093) * *$ & 0.0495 & $(0.0112)^{* *}$ \\
\hline Freshman & -0.0199 & $(0.0105)$ & -0.1126 & $(0.0118) *$ \\
\hline Sophomore & -0.0017 & $(0.0089)$ & -0.0897 & $(0.0100)$ \\
\hline Junior & 0.0046 & $(0.0074)$ & -0.0337 & $(0.0088)$ \\
\hline Female & 0.0143 & $(0.0060)^{* *}$ & 0.0617 & $(0.0074)^{* *}$ \\
\hline Black & 0.1535 & $(0.0177)^{* *}$ & 0.3011 & $(0.0213)^{* *}$ \\
\hline Asian & 0.0184 & $(0.0118)$ & -0.0212 & $(0.0140)$ \\
\hline Hispanic & 0.0675 & $(0.0165)^{* *}$ & 0.1434 & $(0.0203)^{* *}$ \\
\hline Married & -0.0011 & $(0.0139)^{* *}$ & 0.0539 & $(0.0198)$ \\
\hline GPA (3.0-3.5) & 0.0492 & $(0.0076)^{* *}$ & 0.1002 & $(0.0092)^{* *}$ \\
\hline GPA (2.0-2.9) & 0.1302 & $(0.0094)^{* *}$ & 0.2411 & $(0.0109)^{* *}$ \\
\hline $\operatorname{GPA}(<2.0)$ & 0.2450 & $(0.0349)^{* *}$ & 0.3604 & $(0.0331)^{* *}$ \\
\hline Out-of-state resident & -0.0050 & $(0.0100)$ & -0.0372 & $(0.0121)$ \\
\hline International student & 0.0994 & $(0.0238)^{* *}$ & -0.0181 & $(0.0250)^{* *}$ \\
\hline $1^{\text {st }}$ generation college student & 0.0003 & $(0.0068)$ & 0.0157 & $(0.0086)$ \\
\hline Rents an apartment & 0.0218 & $(0.0068)^{* *}$ & 0.0449 & $(0.0085) * *$ \\
\hline Parents own home & -0.0376 & $(0.0098)^{* *}$ & -0.0676 & $(0.0126)^{* *}$ \\
\hline Income/month (\$1-\$249) & 0.0046 & $(0.0085)$ & 0.0169 & $(0.0104)$ \\
\hline Income/month $(\$ 250-\$ 499)$ & 0.0311 & $(0.0084)^{* *}$ & 0.0628 & $(0.0103)^{* *}$ \\
\hline Income/month $(\$ 500-\$ 749)$ & 0.0637 & $(0.0119)^{* *}$ & 0.1286 & $(0.0141)^{* *}$ \\
\hline Income/month(\$750-\$999) & 0.0442 & $(0.0157)^{* *}$ & 0.1080 & $(0.0198)^{* *}$ \\
\hline Income/month $(\geq \$ 1,000)$ & 0.0655 & $(0.0151)^{* *}$ & 0.1219 & $(0.0184)^{* *}$ \\
\hline Town/city (pop 2,500-20,000) & -0.0335 & $(0.0098)^{* *}$ & -0.0665 & $(0.0122)^{* *}$ \\
\hline City (pop 20,000-99,999) & -0.0172 & $(0.0080) * *$ & -0.0274 & $(0.0102) * *$ \\
\hline City (pop 100,000 or more) & -0.0067 & $(0.0079)$ & -0.0222 & $(0.0099)$ \\
\hline Has taken personal finance course & -0.0252 & $(0.0063)^{* *}$ & -0.0423 & $(0.0078) * *$ \\
\hline Finances likely to affect degree & 0.0661 & $(0.0100)^{* *}$ & 0.0693 & $(0.0123) * *$ \\
\hline Finances somewhat likely to affect degree & 0.0470 & $(0.0084)^{* *}$ & 0.0756 & $(0.0104)^{* *}$ \\
\hline Observations & & 19,477 & & 19,477 \\
\hline $\mathrm{R}^{2}$ & & 0.1167 & & 0.2006 \\
\hline
\end{tabular}


with lower grade point averages and earning more per month, and thus working more hours, are also more likely to be at risk. Of all of these, the factors that appear to have the largest effects are being black, Hispanic, having a grade point average below 2.9, and a monthly income above \$1000. Black and Hispanic students are 13.9 and 8.9 percentage points more likely to have credit card balances over $\$ 1000$ than white students, respectively. Those with grade point averages between 2.0 and 2.9 are 13.5 percentage points more likely than those with grade point averages above 3.0, and those with grade point averages below 2.0 are 22.7 percentage points more likely.

With respect to financial education, Table 8 reveals that students who have taken or are currently taking a personal finance course are significantly less likely to be at risk for accumulating large credit card balances but only by 1.6 percentage points. Not surprisingly, those students who believe their financial situation is likely to affect their ability to complete their college degree are more likely to be at risk. Factors that appear to decrease the probability of having credit card balances of $\$ 1000$ or more include being an out-of-state resident and having parents who own their home.

\section{Probability of Being Delinquent on Credit Card Payments}

The results for the probit model for the probability a student is delinquent on their credit card payments by two months or more are fairly consistent with the findings from the previous model. However, the percentages tend to be somewhat smaller. Even so, several factors continue to have a significantly large impact on the likelihood that a student is financially at-risk. Students who acquired their credit card at a campus table are 14.5 percentage points more likely to be delinquent than those who acquired their card from their parents. In addition, being black significantly increases the likelihood of delinquency by 11.1 percentage points. A grade point average below 2.9 continues to result in a significantly large effect. Unlike the previous model, monthly income and being a first-generation college student do not appear to significantly affect the probability of delinquency.

\section{Probability of Having Reached Limit on Credit Cards}

In comparing the results for the probit model for the probability students have reached the limit on their credit cards with the previous two models, the findings are again similar. The factors having the greatest impact continue to be being black, having lower grade point averages, and acquiring credit cards at a campus table rather than from one's parents. However, unlike the previous two models, the results from Table 8 show that international students are 9.9 percentage points more likely to "maxout" their credit cards than domestic students. This finding is perhaps not surprising since international students do not have as many financial options available to cover their education costs and daily living expenses. Interestingly, previous financial education has a larger effect on the probability a student reaches the limit on their credit cards than on 
whether they have accumulated large credit card balances or been delinquent on their payments. Students who have taken or are currently taking a personal finance course are 2.5 percentage points less likely to "maxout" their credit cards.

\section{Probability of Not Paying Balances in Full}

The results from the fourth and final model for the probability students only pay off their credit card balances some of the time or never are, not surprisingly, consistent with the previous models. However, the extent to which various factors affect financial risk is significantly larger. Students who have $\$ 10,000$ or more in financial aid are 17.6 percentage points more likely to not repay their balances and those holding some type of other debt are 13.5 percentage points more likely. Being black or Hispanic increases the probability of not repaying balances by 30.1 and 14.3 percentage points, respectively. As in the other models, students with lower grade point averages and those who acquired their cards at a campus table are significantly more likely to be at risk. However, in this model, being female also increases the likelihood of not repaying balances by 6.2 percentage points. Financial education continues to have an effect and that effect is larger than for previous models. Students who have taken or are currently taking a personal finance course are 4.2 percentage points more likely to repay their credit card balances in full.

\section{Summary of Major Findings}

- $\quad$ Overall, the credit practices of Midwest college students appear to be very similar to other colleges and universities around the country. The majority of students have credit cards (78.8\%), and most students appear to be using them responsibly and not accumulating large amounts of debt. $15.7 \%$ of the students sampled reported balances over $\$ 1000$ and $7.5 \%$ reported balances over $\$ 3000$ compared to about $15.0 \%$ and $5.0 \%$, respectively, for other studies. In addition, over $75.0 \%$ of students reported paying off their entire credit card balance each month-other studies report figures of between $50.0 \%$ and $60.0 \%$.

- While the majority of Midwest college students appear to be using credit responsibly, this study identifies specific groups on college campuses that are more at risk than others for mismanaging and misusing credit. These students are at risk of accumulating large credit card balances and in turn accruing high interest payments. They are further at risk of not being able to repay their debts when they graduate. For the purposes of this study, students were identified as being "financially at-risk" if they had one or more of the following characteristics: credit card balances of $\$ 1000$ or more, delinquent on their credit card payments by two months or more, reached the limit on their credit cards, and only pay off their credit card balances some of the time or never. 
- $\quad$ Financially at-risk students are more likely than those not at risk to be financially independent from their parents, to be receiving some type of financial aid, and to be holding substantial balances of other types of debt such as a car loan, mortgage, or other personal loan. These students are also more likely to have lower grade point averages, to be working more hours, and to report higher earnings. Students with credit card debt are much more likely to owe more in financial aid loans as well as other types of debt. Thus, those with credit card debt are more likely to borrow more in general. These findings suggest that the rising costs of obtaining a college education may be playing a key role in the rise of credit usage on college campuses. Almost $50.0 \%$ of students receiving financial assistance reported that they had charged school related items to their credit cards, because financial aid was not enough to cover their college costs. Current levels of financial assistance may not be enough to cover the rising costs of college. Those students most in need of financial assistance may be forced to work more than 20 hours per week and to turn to other forms of borrowing such as credit cards to complete their college degree. In the end, those who are likely to be at greatest financial risk may be low-to-middle income students.

- $\quad$ The findings from this investigation also indicate that how students acquire their credit cards has a significant effect on a student's ability to manage their credit. Financially atrisk students are more likely than other students to acquire the credit card they use the most from a campus table, over the phone, or online rather than from their parents. These findings suggest that aggressive marketing practices by credit card companies to target college students have likely contributed to the recent rise in credit card debt on college campuses putting some students at more financial risk than others.

- With respect to demographics, the findings from this report also reveal that financially atrisk students are more likely to be female, black, and/or Hispanic. It is interesting to note that these students belong to groups that have historically had difficulty obtaining credit (i.e. women, minorities, and low-income individuals). Of these three groups, black students are the most likely to be at risk, especially for having large debt burdens and mismanaging and misusing their credit cards. Given these findings, groups such as minorities and women may have specific financial education needs. Appropriate financial interventions are needed to insure that these students are not at a financial disadvantage when they graduate.

- Regardless of financial risk, students prefer to receive financial information in one-onone discussions, on the Internet, and in a packet of printed materials rather than during a campus workshop, seminar, or in a formal course. The majority of students $(72.1 \%)$ would, however, register for a course related to personal finance if it was free to students and/or they received course credit. Financially at-risk students would be more likely to enroll in the course, which is interesting since students who have taken or are currently taking a personal finance course are significantly less likely to be financially at-risk. 
- $\quad$ Students also expressed a preference for receiving financial information from financial experts/professionals, their parents, and financial aid counselors rather than their peers, professors, or on their own. In addition, this report shows that students who seek out financial information, especially from their parents and financial institutions, are less likely to be at risk. Interestingly, financially at-risk students are significantly less likely to prefer receiving financial information from their parents and more likely to prefer receiving information from financial aid counselors or on their own. These findings suggest that parents of financially at-risk students may not be as financially knowledgeable as the parents of students who are not at risk. There may be a need to provide financial education to both financially at-risk students and their parents.

- $\quad$ Finally, recent media reports have focused on growing concerns that students are accumulating too much debt to the point that they are unable to repay these debts when they graduate. Despite this recent attention, very little is known about the actual consequences of financial strain, especially students' ability to manage their accumulated debt after graduation. This report shows that about 1 in 3 students believe that their financial situation is "likely" or "somewhat likely" to affect their ability to complete their college degree. $16.0 \%$ of students report that, because of their financial situation, they had to reduce their number of credit hours and 5.6\% had to drop out for a semester. This report also reveals that 1 in 3 students are having difficulty concentrating on their studies and more than 1 in 4 have experienced physical or mental discomfort because of their financial situation. About $50.0 \%$ of financially at-risk students report that their financial situation has affected their health. Overall, financially at-risk students are more likely than those not at risk to indicate that their financial situation is affecting their ability to complete their degree or their health and well-being. These are just a few of the ways in which financial burden appears to be affecting students. However, longitudinal studies are needed to examine in more depth the role that credit plays in the post-college lives of students.

\section{Where Do We Go From Here?}

Campuses administrators face a number of challenges in designing programs and providing resources to address the financial education needs of college students. Given the diverse needs of various groups of students, it may seem like "one size does not fit all" when it comes to financial education. However, the findings from this report provide substantial insight into the types of services and programs that are likely to meet a wide-range of students' preferences and financial education needs.

In this section, recommendations are made to campus administrators and financial professionals on how they can develop and administer effective resources and services that address the financial education needs of students, especially those who are most at risk. Appropriate 
interventions are needed to insure that students are not at a financial disadvantage when they graduate and are able to make informed financial decisions. The recommendations below are in no particular order of priority.

\section{Recommendations for Campus Administrators}

- $\quad$ First, campus administrators may want to consider providing financial aid offices with additional resources for financial services and programs, particularly given students' preferences for receiving financial information from financial aid counselors and in small group settings. They may also want to consider offering one-on-one financial counseling and planning and developing a financial counseling clinic that operates either within or outside of the financial aid office. For example, at Brigham Young University (BYU), students are required to file a financial plan with the Financial Aid Office before their loan eligibility is certified (Weston, 2001). Filing a financial plan makes students aware of how much they will need to borrow to finance their education. It also helps students to identify whether or not they will be able to repay their loans after graduation and still maintain a comfortable standard of living. As a result of BYU's counseling program, Stafford Loan amounts have decreased substantially.

- While one-on-one interaction may be preferred by students, it is time and resource intensive to offer these types of financial services. Moreover, regardless of resources, financial aid offices may be ill-equipped to provide these services, especially financial counseling and planning. If colleges are faced with limited resources, campus administrators may want to consider forming partnerships with other campuses or local community organizations such as Cooperative Extension or Consumer Credit Counseling Services (CCCS). These non-profit organizations frequently help students with debt management and other financial needs.

- $\quad$ At the very minimum, campuses should consider offering a course on credit and financial management to provide students early in their college careers with the basic skills and tools necessary to become responsible financial consumers. Recall that over $70.0 \%$ of students indicated that they would register for a course related to personal finance. Campuses may want to consider offering such a course through their continuing education departments, which have been successful at delivering financial education to adults.

- $\quad$ Campus administrators may also want to offer workshops to incoming students along with their parents as part of freshman orientation. The financial instruction could include subjects related to budgeting, managing your financial aid, and using credit responsibly. Efforts are already underway on a number of campuses to include some type of financial education as part of freshman orientation or during students' first year on campus. Targeting student groups and organizations that are predominately comprised of women 
and minorities may be particularly effective given that these groups are at greater risk than others.

- $\quad$ Another effective delivery method for disseminating financial information to students may be over the Internet, which was also listed as a preferred way to receive financial information. However, campus administrators need to be cautious when considering the Internet as an effective mode of delivery for financial education. While it is a quick and cost effective way to disseminate financial information and resources, it may be difficult to reach students if a large fraction of them do not have easy access to the Internet when they are both on and off campus. A number of financial aid offices have begun providing online financial services to their students. For example, the Office of Student Financial Aid at the University of Illinois at Urbana-Champaign has implemented a web-based customer support site called "Ask Us," which can be accessed through their website at: http://www.osfa.uiuc.edu. "Ask Us" provides students and parents 24-hour access to an online question and answer service for issues related to financial aid. Student feedback regarding "Ask Us" has been extremely positive.

- $\quad$ Recall that students who acquire credit cards at campus tables are more financially at-risk than others. For this reason, campus administrators may want to re-evaluate their current policies with respect to whether or not credit card companies should be allowed on their campus. Administrators may want to require that credit card vendors hand out materials on responsible credit card usage along with credit card applications. They may also want to require that vendors conduct educational workshops and seminars.

- $\quad$ This report provides evidence that students' financial situations are likely affecting 1) their ability to complete their college degrees and 2) their physical and mental well-being. Given these findings, a number of campus offices and organizations may want to be involved in a financial education campaign (i.e. student affairs, financial aid, health and counseling centers, the career center, campus housing, and student government.)

- Campus administrators need to find ways to get students involved in the development of financial education programs and initiatives on their campus. Opportunities for students to participate in the planning and development of programs and resources helps campuses to better meet the needs of their students. Also, student involvement is more likely to result in a successful outreach campaign.

\section{Implications for Financial Professionals}

College students primarily turn to their campuses for financial information. However, some campuses may lack the funds needed to provide these resources. In these cases, financial counseling and planning professionals can serve as a valuable resource to campuses that are interested in addressing the financial education needs of their students. 
A number of opportunities exist for financial professionals to provide financial information to this clientele base. Financial professionals may want to consider linking with college campuses to provide financial planning and counseling services and seminars and workshops. These resources have the potential to not only benefit students but parents and the community as well.

\section{Final Comments}

The main objectives of this report have been to 1) provide greater insight into the credit practices and financial education needs of Midwest college students and 2) to identify ways in which campus administrators and financial professionals can help students better manage their credit and avoid future misuse of credit down the road. This report provides some intriguing findings, especially with respect to those students who are most likely to be financially at-risk. However, there is still much work to be done before our understanding is complete. The author of this report encourages campus administrators, financial professionals, community leaders, and other researchers to use this report as a foundation for future research and the development of future financial education programs and initiatives. 


\section{References}

Allen, J. L. \& Joyce, M. A. (1997). Credit Card Behavior of University Students: Ethnic Differences. Consumer Interest Annual 43, 162-170.

Armstrong, C. J. \& Craven, M. J. (1993). Credit card use and payment practices among college students. Proceedings of the $6^{\text {th }}$ Annual Conference of the Association for Financial Counseling and Planning Education, 148-159.

Asinof, L. \& Chaker, A. M. (2002). College planning: Families scramble to pay tuition; colleges begin offering new aid. The Wall Street Journal, July 18th.

Baek, E. (2001). Financial Concerns and Problems of College Students. Proceedings of the Association for Financial Counseling and Planning Education, 16-25.

Baum, S. \& O'Malley, M. (2003). College on credit: How borrowers perceive their education debt. 2002 National Student Loan Survey, Nellie Mae Corporation, accessible at http://www.nelliemae.com/library/nasls 2002.pdf.

Blaum, P. (2000). How Students Use Credit Cards Has Greater Impact Than Number of Cards.”Pennsylvania State University,pab15@psu.edu, May 10th.

Chen, H. \& Volpe, R. P. (1998). An analysis of personal financial literacy among college students. Financial Services Review, 7(2), 107-128.

Doll, K. (2000). Who would use financial counseling and planning services on university campuses? Evidence from students, staff and faculty. Proceedings of the Association for Financial Counseling and Planning and Education, 122-131.

The Education Resources Institute \& The Institute for Higher Education Policy (TERI \& IHEP). (1998). Credit Risk or Credit Worthy? College Students and Credit Cards. Boston, MA.

Fossey, R. (1998). The dizzying growth of the federal student loan program: When will vertigo set in?” In R. Fossey \& M. Bateman (Eds.), Condemning Students to Debt: College Loans and Public Policy. New York: Teachers College Press, Columbia University.

Hansen, W. \& Rhodes, M. (1988). Student Debt Crisis: Are Students Incurring Excessive Debt? Economics of Education Review, 7, 101-112.

Hayhoe, C. (2002). Comparison of affective credit attitude scores and credit use of college students at two points in time. Journal of Family and Consumer Sciences, 94(1), 71-77. 
Hayhoe, C., Leach, L., Turner, P., Bruin, M., \& Lawrence, F. (2000). Differences in Spending Habits and Credit Use of College Students. Journal of Consumer Affairs, 34, 113-133.

Hayhoe, C., Leach, L. \& Turner, P. (1999). Discriminating the number of credit cards held by college students using credit and money attitudes. Journal of Economic Psychology, 20, 643-656.

Illinois Community College Board. (2002). Facts about Community Colleges, accessible at http://www.iccb.state.il.us/HTML/system/facts.html.

The Institute for Higher Education Policy, Sallie Mae Education Institute, and The Education Research Institute. (1998). Student Loan Debt: Problems and Prospects. Proceedings from a National Symposium. Washington, D.C.

Jamba-Joyner, L. A., Howard-Hamilton, M., \& Mamarchew, H. (2000). College Students and Credit Cards: Cause for Concern. NASFAA Journal of Student Financial Aid, 30, 17-25.

Johnstone, B. (1996). The United States. In D. W. Breneman, Leslie, L. L., \& El Anderson, R. (Eds.), ASHE Reader on Finance in Higher Education. Needham Heights, MA: Simon and Schuster.

Joo, S., Grable, J. \& Bagwell, D. (2001). College students and credit cards. Proceedings of the Association for Financial Counseling and Planning Education, 8-15.

Lyons, A. C. (2004). A profile of financially at-risk college students. The Journal of Consumer Affairs, forthcoming.

Lyons, A. C. (2003). A Qualitative Study on Providing Credit Education to College Students: Perspectives from the Experts." University of Illinois at Urbana-Champaign. Unpublished manuscript.

Lyons, A. C. \& Andersen, P. (2002). Credit Usage of College Students: Evidence from the University of Illinois. The Office of Student Financial Aid Research Report, University of Illinois at Urbana-Champaign, April 2002.

Lyons, A. C. \& Hunt, J. L. (2003). The credit practices and financial education needs of community college students. Financial Counseling and Planning Journal, forthcoming.

Lyons, Angela, Brenda Cude, Michael Gutter, and Frances Lawrence. 2003. The Challenges of Online Surveying: What Should Researchers Know? Working paper.

Pilcher, A. \& Haines, T. (2000). Peer financial counseling: From one student to another. Proceedings of the Association for Financial Counseling and Planning Education, 132. 
Riggle, T. (2001). University to Inform Students About Credit Cards. The Exponent Online. Purdue University, April 13th.

Roberts, J. \& Jones, E. (2001). Money Attitudes, Credit Card Use, and Compulsive Buying Among American College Students. The Journal of Consumer Affairs, 35, 213-240.

Rohrke, A. (2002). A closer look at personal finance. Econ Ed \& the Fed. The Federal Reserve Bank of San Francisco, pp. 1-3.

Shenk, J. W. (1997). In debt all the way up to their nose rings. U.S. News \& World Report, June 9th, pp. 38-39.

Staten, M. \& Barron, J. (2002). College student credit card usage. Credit Research Center, Working Paper \#65. Georgetown University.

United States General Accounting Office. (2001). Consumer Finance: College Students and Credit Cards. Report to Congressional Requesters (GAO-01-773).

Varcoe, K., Peterson, S., Garrett, C., Martin, A., René, P. \& Costello, C. (2001). What teens want to know about financial management. Journal of Family and Consumer Sciences, 93(2), 30-34.

Weston, M. B. (2001). Creating a financial path to graduation. Proceedings of the Association for Financial Counseling and Planning Education, 131.

Xiao, J., Noring, F. \& Anderson, J. (1995). College students' attitudes towards credit cards. Journal of Consumer Studies and Home Economics, 19, 155-174.

Zhou, L. and Hu, H. J. (2000). Predicting College Student Debt: An Exploratory Study on Behavioral Determinants. Proceedings of the Association for Financial Counseling and Planning Education, 133-140. 


\title{
Appendix A: The Survey
}

\section{Student Credit Usage and Fi nanci al Educati ON J ANUARY 2003}

\author{
Conducted by \\ Dr. Angela Lyons \\ University of Illinois at Urbana-Champaign
}

Thank you for choosing to participate in our survey. Dr. Angela Lyons and educators from the State of Illinois are conducting research to learn more about student credit usage and the need for financial education on college campuses.

Your answers are very important, because they will help to develop a new financial education program called \$tudent \$marts. The purpose of the program is to develop resources and materials to help college students build financial knowledge, make informed financial decisions, use financial services responsibly, and develop a sense of financial independence.

If you are 18 years of age, or older, you may participate in the survey and that participation is strictly voluntary. You may refuse to participate or discontinue participation at any time. There is no penalty. Your decision to participate will not affect your present or future relations with your college or the University of Illinois. However, by deciding to complete the survey, you will provide us with valuable information about how credit usage may be affecting today's college students.

All of your survey responses will be kept strictly confidential. Your responses will be seen only by authorized members of our staff. Data gathered for this project will be analyzed as a whole, excluding references to any individual student. Only the results of our analysis will be shared with researchers and organizations who are interested in providing services to students about credit usage and money management.

Undergraduate students are being contacted at eight campuses in the state of Illinois as well as Purdue University, University of Missouri-Columbia, and University of WisconsinMadison.

The survey will take you about 10 minutes to complete, and you will have a chance to win one of three $\mathbf{\$ 1 5 0}$ gift certificates to BEST BUY! Each student who completes the survey will have the opportunity to compete in the drawing. Winners will be notified by email in 3-4 weeks. Good Luck!

Please respond no later than - Friday, February $\mathbf{2 8}^{\text {th }}$.

Thank you once again for your participation!

Questions or concerns about the survey may be directed to Dr. Angela Lyons (217.244.2612; anglyons@uiuc.edu.) For information about your rights as a research subject, please contact the UIUC IRB (217.333.2670; irb@uiuc.edu.) 


\section{Section 1: Current Credit Usage and Knowledge:}

1. Do you have a credit card?

\begin{tabular}{ll} 
Yes & (if "Yes," continue to QUESTION 2) \\
\hline & (if "No," SKIP to QUESTION 13)
\end{tabular}

If your answer to question 1 is "No," skip to question 13. If your answer to question 1 is "Yes," continue to question 2.

2. How many credit cards do you have in your name? (Include bank cards, store cards, etc.) One

\begin{tabular}{ll}
\hline & Two \\
Three \\
\hline & Four \\
& Five or more
\end{tabular}

3. How frequently do you use your credit card(s)? Almost daily A few times a week A few times a month Rarely Emergency only

4. When did you obtain your first credit card? Before beginning college First year of college After first year of college

5. What is the TOTAL amount you currently owe on ALL of your credit cards? $\$ 0$ (I do not owe any money) $\$ 1-\$ 499$ $\$ 500$ - \$999

$\$ 1,000-\$ 2,999$

$\$ 3,000-\$ 4,999$

$\$ 5,000-\$ 9,999$

$\$ 10,000$ or more Not sure

6. In the last few years, have you ever been late on any of your credit card payments by 2 months or more? Yes No

7. How often do you pay off the ENTIRE BALANCE on your credit card(s)? Almost always Sometimes Never

8. How often do you "MAX OUT" your credit card(s)? Almost always Sometimes Never 
9. How did you acquire the credit card you use the MOST?

A mail application

At a campus table

At a bank/financial institution

At a retail store

Over the phone

Online

Parents

Other

10. What is the "Annual Percentage Rate" (APR) for the credit card you use the MOST?

Less than $5 \%$ APR

$5 \%-9 \%$ APR

$10 \%-14 \%$ APR

$15 \%-20 \%$ APR

Higher than $20 \%$ APR

Not sure

11. What is the total "maximum amount" you can charge on the credit card you use the MOST? $\$ 0-\$ 499$

$\$ 500$ - \$999

$\$ 1,000-\$ 2,999$

$\$ 3,000-\$ 4,999$

$\$ 5,000$ or more

Not sure

12. What do you usually purchase with your credit card(s)? (Check all that apply)

Textbooks/school supplies

Tuition and fees

Clothes and other personal items

Groceries

Eating out

Entertainment (movies, dance clubs, etc.)

Gas/auto maintenance/auto repair

Travel (airfare, hotel, rental car)

Rent/utilities

Other bills (cable, internet, cell phone)

Expenses related to Fraternity/Sorority/Professional organizations

Other

13. What type(s) of Financial Aid have you received? (Check all that apply)

No Financial Aid at this time

Federal student loans (i.e. Stafford, Direct)

Federal parent loans (PLUS)

Alternative loans (private loans)

Federal work-study

Need-based grants (i.e. PELL, MAP)

Scholarships

Tuition waiver 
14. How much do you currently owe with respect to financial aid loans?

$\$ 0$, I have no financial aid loans

$\$ 1-\$ 4,999$

$\$ 5,000-\$ 9,999$

$\$ 10,000-\$ 19,999$

$\$ 20,000-\$ 29,999$

$\$ 30,000-\$ 39,999$

$\$ 40,000-\$ 49,999$

$\$ 50,000$ or more

Not sure

15. Are there school items (i.e. textbooks, tuition, fees) that you charge to your credit card(s), because student financial aid is not enough to cover the cost? Yes No

16. What other type(s) of loans do YOU personally have (do not include loans for which you are NOT personally responsible for the repayment)? (Check all that apply) No other loans at this time

Car loan Mortgage Installment loan (i.e. for stereo, PC, other electronics, furniture) Informal loan from family/friends

Private loan from a financial institution (bank, credit union) Other

17. NOT including credit card debt and financial aid loans, approximately how much other debt do you currently owe? $\$ 0$

$\$ 1-\$ 999$

$\$ 1,000-\$ 2,999$

$\$ 3,000-\$ 4,999$

$\$ 5,000-\$ 9,999$

$\$ 10,000$ - $\$ 19,999$

$\$ 20,000$ or more

Not sure

\section{Section 2: Financial Education}

18. If you were in need of personal finance information, how would you MOST like to receive this information? (Check all that apply) At a campus workshop/seminar

In a formal college course

In a packet of printed materials (i.e. pamphlets and handouts)

On the Internet

In one-on-one discussion with a financial professional 
19. Who would you MOST like to receive this information from? (Check all that apply)

Professors

Other students/peers

Financial aid counselors

Financial experts/professionals

Parents

Would prefer to receive this information on my own

20. In the last few years, where or from whom did you find the most useful information about credit?

(Check all that apply)

Parents

Friends

High school or college course

Internet

Financial institutions

Non-profit organizations or businesses

Books, magazines, and newspapers

TV and radio

Have not gone to find information

21. How important is each financial topic to you? Please rank on a scale from 1 to 5 with 1 being very important and 5 being not important at all.

Personal financial management and budgeting

Credit cards and terms

Shopping for a car loan

Financing a college education

Saving and investing

Planning for retirement

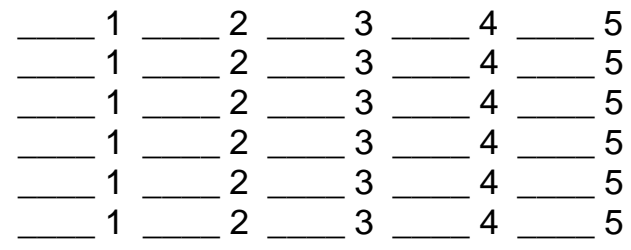

22. How well is your understanding of each financial topic? Please rank on a scale from 1 to 5 with 1 being complete understanding and 5 being no understanding at all.

Personal financial management and budgeting

Credit cards and terms

Shopping for a car loan

Financing a college education

Saving and investing

Planning for retirement

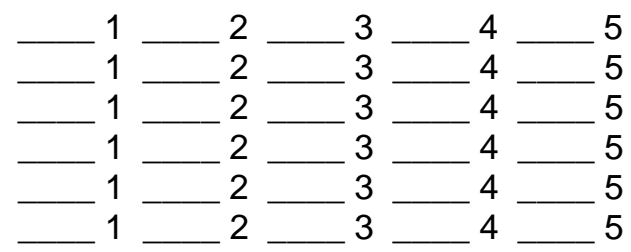

23. Would you register for an in-person course related to personal finance if offered on campus? (Check only one)

Yes, only if the class was free

Yes, only if the class was offered for course credit

Yes, regardless of whether the class was free or offered for credit No

24. Would you register if the course was offered online? (Check only one)

Yes, only if the class was free

Yes, only if the class was offered for course credit

Yes, regardless of whether the class was free or offered for credit No 
25. Have you taken or are you currently taking any courses in high school or college related to personal finance?

Yes

No

\section{Section 3: Some Information About You:}

26. What year are you in school?

Freshman

Sophomore

Junior

Senior

Just graduated (Fall 2002)

Other

27. What is your age?

18-19

20-21

22-23

$24-25$

26-29

30-39

40-49

50 or older

28. What is your gender?

Male

Female

29. What is your primary ethnic background?

African American/Black

Asian

Hispanic

Native American

White

Other

30. What is your marital status?

Single with no children

Single with children

Married with no children

Married with children

Living as a couple

31. What is your current GPA?

$3.6-4.0+$
$3.0-3.5$
$2.6-2.9$
$2.0-2.5$
Lower than 2.0


32. How many credit hours are you registered for this semester? Less than 6 hours

6-12 hours

13-15 hours

16-18 hours

19 or more hours

33. Are you the first person in your immediate family to go to college? Yes No

34. What is your father's level of education? Less than high school Completed high school Some college College degree (B.A., B.S.)

Graduate school or professional degree (i.e. M.A., M.B.A, Ph.D.)

35. What is your mother's level of education? Less than high school Completed high school Some college College degree (B.A., B.S.)

Graduate school or professional degree (i.e. M.A., M.B.A, Ph.D.)

36. Are you financially independent from your parents (i.e. parents do not claim you on their tax return)?

$\underset{\text { Nos }}{\text { No }}$

37. What is your residential status?

In-state student

Out-of-state student

International student

38. What type of housing do you currently live in?

Residence Hall

Fraternity/Sorority

Apartment (rent)

House (rent)

Live at home with parents/relatives

Other

39. What is the population of your home town?

Rural area with population under 2,500

Town/City with population 2,500-20,000

City with population $20,000-99,999$

City with population over 100,000

40. Are you currently a full-time or part-time student?

Full-time

Part-time

Other 
41. On average, how many hours a week do you work?

$0 \mathrm{hrs} / \mathrm{wk}$, I am not employed at this time

- $1-10 \mathrm{hrs} / \mathrm{wk}$

$11-15 \mathrm{hrs} / \mathrm{wk}$

$16-20 \mathrm{hrs} / \mathrm{wk}$

20-29 hrs/wk

More than $30 \mathrm{hrs} / \mathrm{wk}$

42. On average, what is YOUR monthly income from work?

$\$ 0$ (I am not employed at this time.)

$\$ 1-\$ 249$

$\$ 250--\$ 499$

$\$ 500-\$ 749$

$\$ 750-\$ 999$

$\$ 1000-\$ 1999$

$\$ 2000-\$ 2999$

$\$ 3000-\$ 3999$

$\$ 4000-\$ 4999$

More than $\$ 5000$

43. What is YOUR PARENT(S) annual income? (Give an approximate amount) Less than $\$ 25,000$

$\$ 25,000--\$ 49,999$

$\$ 50,000-\$ 74,999$

$\$ 75,000-\$ 99,999$

$\$ 100,000$ or more

Not sure

44. Do your parent(s) own or rent the residence they live in?

Own

Rent

Other

45. How likely is it that your financial situation will make it difficult to complete your college degree? very likely

likely

somewhat likely

not likely

not likely at all

46. Have you ever reduced the number of credit hours you were taking so that you could work more hours to pay your expenses?

$$
\begin{aligned}
& \text { Yes } \\
& \text { No }
\end{aligned}
$$

47. Have you ever dropped out for a semester so that you could work more hours to pay your expenses?

Yes
No

48. Does your financial situation affect your ability to concentrate on your studies? Yes

No 
49. Do you find yourself losing sleep or experiencing physical discomfort because of your financial situation?

$$
\begin{aligned}
& \text { Yes } \\
& \text { No }
\end{aligned}
$$

50. Which parent are you more likely to go to for financial advice?

Mother

Father

51. Which parent is more likely to pay the bills in your family? Mother

Father

52. What institution did you attend in Fall 2002?

Bradley University

Illinois State University

Northern Illinois University

Southern Illinois University-Carbondale

University of Illinois at Chicago

University of Illinois at Springfield

University of Illinois at Urbana-Champaign

Western Illinois University

Purdue University

University of Missouri-Columbia

University of Wisconsin-Madison

Other

\section{Section 4: Contact Information for Prize Drawing}

Please review your answers to this survey. All information you have submitted will be kept strictly confidential. Only authorized members of our staff will have access to the data for analysis. Results of the survey will be analyzed as a whole and no references will be made to any individual's information.

If you would like your name to be included in the random drawing for one of three $\$ 150$ gift certificates to BEST BUY, please fill in the box below with your campus e-mail address.

Your e-mail address will not be linked to your survey information and will be immediately erased from the database following the drawing.

Winners will be notified by e-mail within 3-4 weeks of the closing date-Friday, February $28^{\text {th }}, 2003$.

50. Please enter my name in the random drawing (optional).

My email address is:

\section{Thank you for completing our survey!}




\section{Appendix B: The E-mail Invitations}

\section{First E-mail: This e-mail was sent to invite college students to participate in the Student Credit Usage and Financial Education Survey.}

From: Dr. Angela Lyons

Subject: Survey: Tell Us What You Think!

$\mathrm{Hi}$,

I am Dr. Angela Lyons at the University of Illinois at Urbana-Champaign. UIUC is one of several college campuses participating in a research project on student credit usage and financial knowledge. I would like to invite you to participate.

I am working with educators from the state of Illinois to develop a new financial literacy program called \$tudent \$marts. The purpose of the program is to develop resources and materials to help college students make informed financial decisions related to credit usage. We need your help in learning more about how students are using credit. We hope that you will choose to participate in our survey.

If you are 18 years of age, or older, you may participate in the survey and that participation is strictly voluntary. You may refuse to participate or discontinue participation at any time. There is no penalty. Your decision to participate will not affect your present or future relations with the University of Illinois. However, by deciding to complete the survey, you will provide us with valuable information about how credit usage may be affecting today's college students.

Any and all information we receive will be kept strictly confidential and will only be seen by authorized members of my staff. Data gathered from the survey will be analyzed as a whole, excluding all references to any individual students. Only the results of the analysis will be shared with researchers and organizations interested in providing services to students about credit usage and money management.

Undergraduate students are being contacted at eight campuses in the state of Illinois as well as Purdue University, University of Missouri-Columbia, and University of Wisconsin-Madison.

The online survey will take you about 10 minutes to complete and you must be 18 years or older to participate. When you are finished, you will be eligible for a random drawing for one of three $\$ 150$ gift certificates to Best Buy. Each student who completes the survey will have the opportunity to compete in the drawing. Winners will be notified by e-mail in 3-4 weeks. Good Luck!

Please respond no later than Friday, February 28, 2003. Click here to access the survey now:

$$
\text { Student Credit Usage and Financial Education Survey }
$$

http://www.ace.uiuc.edu/Infopoll/surveys/s10.htm

Thank you in advance for taking the time to help with this important project and, if you have questions or concerns, contact:

Angela C. Lyons, Assistant Professor

University of Illinois at Urbana-Champaign

429 Mumford Hall, 1301 West Gregory Drive

Urbana, IL 61801

phone: (217) 244-2612

e-mail: anglyons@uiuc.edu 
Second E-mail: This e-mail was sent to the same group of students who were sent the first email inviting their participation. This e-mail was to remind them to participate in the survey.

From: Dr. Angela Lyons

Subject: Survey: Tell Us What You Think!

$\mathrm{Hi}$,

This is a REMINDER ... if you haven't already filled out our survey ... you have another opportunity to help us out!

I am Dr. Angela Lyons at the University of Illinois at Urbana-Champaign. UIUC is one of several college campuses participating in a research project on student credit usage and financial knowledge. I am working with educators from the state of Illinois to develop a new financial literacy program called \$tudent \$marts. The purpose of the program is to develop resources and materials to help college students make informed financial decisions related to credit usage. We need your help in learning more about how students are using credit.

If you are 18 years of age, or older, you may participate in the survey and that participation is strictly voluntary. You may refuse to participate or discontinue participation at any time. There is no penalty. Your decision to participate will not affect your present or future relations with the University of Illinois. However, by deciding to complete the survey, you will provide us with valuable information about how credit usage may be affecting today's college students.

Any and all information we receive will be kept strictly confidential and will only be seen by authorized members of my staff. Data gathered from the survey will be analyzed as a whole, excluding all references to any individual students. Only the results of the analysis will be shared with researchers and organizations who are interested in providing services to educate students about credit usage and money management.

Undergraduate students are being contacted at eight campuses in the state of Illinois as well as Purdue University, University of Missouri-Columbia, and University of Wisconsin-Madison.

The online survey will take you about 10 minutes to complete and you must be 18 years or older to participate. When you are finished, you will be eligible for a random drawing for one of three $\$ 150$ gift certificates to Best Buy. Each student who completes the survey will have the opportunity to compete in the drawing. Winners will be notified by e-mail in 3-4 weeks. Good Luck!

Please respond no later than Friday, February 28, 2003. Click here to access the survey now:

$$
\text { Student Credit Usage and Financial Education Survey }
$$

http://www.ace.uiuc.edu/Infopoll/surveys/s10.htm

Thank you in advance for taking the time to help with this important project and, if you have questions or concerns, contact:

Angela C. Lyons, Assistant Professor

University of Illinois at Urbana-Champaign

429 Mumford Hall, 1301 West Gregory Drive

Urbana, IL 61801

phone: (217) 244-2612

e-mail: anglyons@uiuc.edu 
Third E-mail: This e-mail was sent to the same group of students who were sent the first and second e-mails inviting their participation. This e-mail was a final reminder to participate in the survey.

From: Dr. Angela Lyons

Subject: Survey: Tell Us What You Think!

$\mathrm{Hi}$,

This is a final REMINDER ... if you haven't already filled out our survey ... you have one more opportunity to help us out!

I am Dr. Angela Lyons at the University of Illinois at Urbana-Champaign. UIUC is one of several college campuses participating in a research project on student credit usage and financial knowledge. I am working with educators from the state of Illinois to develop a new financial literacy program called \$tudent \$marts. The purpose of the program is to develop resources and materials to help college students make informed financial decisions related to credit usage. We need your help in learning more about how students are using credit.

If you are 18 years of age, or older, you may participate in the survey and that participation is strictly voluntary. You may refuse to participate or discontinue participation at any time. There is no penalty. Your decision to participate will not affect your present or future relations with the University of Illinois. However, by deciding to complete the survey, you will provide us with valuable information about how credit usage may be affecting today's college students.

Any and all information we receive will be kept strictly confidential and will only be seen by authorized members of my staff. Data gathered from the survey will be analyzed as a whole, excluding all references to any individual students. Only the results of the analysis will be shared with researchers and organizations who are interested in providing services to educate students about credit usage and money management.

Undergraduate students are being contacted at eight campuses in the state of Illinois as well as Purdue University, University of Missouri-Columbia, and University of Wisconsin-Madison.

The online survey will take you about 10 minutes to complete and you must be 18 years or older to participate. When you are finished, you will be eligible for a random drawing for one of three $\$ 150$ gift certificates to Best Buy. Each student who completes the survey will have the opportunity to compete in the drawing. Winners will be notified by e-mail in 3-4 weeks. Good Luck!

Please respond no later than Friday, February 28, 2003. Click here to access the survey now:

Student Credit Usage and Financial Education Survey

http://www.ace.uiuc.edu/Infopoll/surveys/s10.htm

Thank you in advance for taking the time to help with this important project and, if you have questions or concerns, contact:

Angela C. Lyons, Assistant Professor

University of Illinois at Urbana-Champaign

429 Mumford Hall, 1301 West Gregory Drive

Urbana, IL 61801

phone: (217) 244-2612

e-mail: anglyons@uiuc.edu 


\section{Appendix C: Credit Practices and Financial Education Needs by Campus}

Table 1C: Demographic Profile of Students (by campus)

\begin{tabular}{|c|c|c|c|c|c|c|c|c|c|c|c|}
\hline Variable (mean/percentage) & $\begin{array}{c}\text { All } \\
\text { Students }\end{array}$ & $\begin{array}{c}\text { Campus } \\
\# 1\end{array}$ & $\begin{array}{c}\text { Campus } \\
\# 2\end{array}$ & $\begin{array}{c}\text { Campus } \\
\# 3\end{array}$ & $\begin{array}{c}\text { Campus } \\
\# 4\end{array}$ & $\begin{array}{c}\text { Campus } \\
\# 5\end{array}$ & $\begin{array}{c}\text { Campus } \\
\# 6\end{array}$ & $\begin{array}{c}\text { Campus } \\
\# 7\end{array}$ & $\begin{array}{c}\text { Campus } \\
\# 8\end{array}$ & $\begin{array}{c}\text { Campus } \\
\# 9\end{array}$ & $\begin{array}{c}\text { Campus } \\
\# 10\end{array}$ \\
\hline \multicolumn{12}{|l|}{ Demographics } \\
\hline Freshmen & 23.6 & 29.0 & 21.5 & 28.9 & 17.7 & 22.5 & 15.4 & 23.5 & 23.3 & 29.0 & 21.9 \\
\hline Sophomore & 22.0 & 21.6 & 19.7 & 20.3 & 14.9 & 20.1 & 10.6 & 24.1 & 17.9 & 22.8 & 25.2 \\
\hline Junior & 25.0 & 23.6 & 28.1 & 25.9 & 26.1 & 27.7 & 38.5 & 24.2 & 29.6 & 22.8 & 22.7 \\
\hline Senior & 29.4 & 25.7 & 30.7 & 24.9 & 41.3 & 29.7 & 35.5 & 28.1 & 29.1 & 25.4 & 30.2 \\
\hline Age $>25$ & 5.1 & 5.3 & 5.5 & 5.5 & 18.7 & 7.8 & 34.9 & 1.2 & 11.6 & 2.9 & 2.4 \\
\hline Female & 58.8 & 63.2 & 67.2 & 64.6 & 53.0 & 63.6 & 68.6 & 56.6 & 63.4 & 48.2 & 61.0 \\
\hline White & 79.3 & 92.0 & 90.3 & 74.8 & 76.0 & 48.0 & 80.5 & 73.9 & 87.0 & 82.5 & 88.0 \\
\hline Black & 4.8 & 3.3 & 3.8 & 9.2 & 13.4 & 8.0 & 7.1 & 5.0 & 5.9 & 2.6 & 1.4 \\
\hline Asian & 9.0 & 1.6 & 2.0 & 5.9 & 3.4 & 24.1 & 2.4 & 13.9 & 1.5 & 9.1 & 6.8 \\
\hline Hispanic & 4.1 & 1.8 & 2.3 & 7.1 & 3.5 & 14.2 & 4.7 & 4.4 & 3.0 & 2.8 & 1.8 \\
\hline Other race & 2.8 & 1.4 & 1.7 & 3.0 & 3.7 & 5.7 & 5.3 & 2.7 & 2.7 & 3.0 & 2.0 \\
\hline Married & 3.9 & 5.1 & 4.1 & 3.0 & 12.9 & 4.2 & 20.1 & 1.3 & 8.0 & 3.8 & 2.1 \\
\hline GPA (3.6-4.0) & 28.5 & 26.1 & 22.3 & 19.0 & 27.9 & 48.8 & 43.8 & 30.4 & 26.5 & 22.3 & 28.5 \\
\hline GPA $(3.0-3.5)$ & 42.6 & 44.8 & 41.6 & 37.7 & 37.1 & 39.4 & 34.9 & 45.5 & 35.8 & 40.8 & 47.2 \\
\hline GPA (2.0-2.9) & 27.3 & 1.4 & 33.9 & 39.4 & 32.5 & 11.7 & 20.1 & 23.2 & 34.7 & 34.6 & 23.3 \\
\hline GPA $(<2.0)$ & 1.6 & 1.4 & 2.1 & 3.9 & 2.5 & 0.1 & 1.2 & 0.9 & 3.0 & 2.4 & 1.0 \\
\hline In-state resident & 86.5 & 85.0 & 98.5 & 97.5 & 91.2 & 97.4 & 97.0 & 90.9 & 95.8 & 68.4 & 76.7 \\
\hline Out-of state resident & 10.9 & 14.6 & 1.0 & 2.0 & 5.6 & 1.5 & 1.2 & 6.8 & 3.4 & 25.1 & 20.3 \\
\hline International student & 2.6 & 0.4 & 0.5 & 0.6 & 3.3 & 1.1 & 1.8 & 2.3 & 0.8 & 6.5 & 3.1 \\
\hline 1st generation college student & 22.9 & 24.0 & 27.1 & 33.3 & 28.8 & 29.5 & 27.8 & 17.8 & 31.3 & 21.2 & 18.8 \\
\hline Financially independent & 19.5 & 17.0 & 19.0 & 24.1 & 41.7 & 28.6 & 57.4 & 10.3 & 29.6 & 17.4 & 16.2 \\
\hline Rents an apartment & 44.4 & 29.2 & 41.1 & 35.3 & 44.5 & 28.8 & 30.8 & 46.2 & 32.0 & 43.7 & 57.7 \\
\hline Parents own home & 89.0 & 90.1 & 90.0 & 84.8 & 82.1 & 82.5 & 89.3 & 90.4 & 84.5 & 89.9 & 93. \\
\hline
\end{tabular}

Note: Percentages may not sum to 100 due to rounding. 
Table 1C (conti.): Demographic Profile of Students (by campus)

\begin{tabular}{|c|c|c|c|c|c|c|c|c|c|c|c|}
\hline Variable (mean/percentage) & $\begin{array}{c}\text { All } \\
\text { Students }\end{array}$ & $\begin{array}{c}\text { Campus } \\
\quad \# 1\end{array}$ & $\begin{array}{c}\text { Campus } \\
\quad \# 2\end{array}$ & $\begin{array}{c}\text { Campus } \\
\quad \# 3\end{array}$ & $\begin{array}{c}\text { Campus } \\
\quad \# 4\end{array}$ & $\begin{array}{l}\text { Campus } \\
\quad \# 5\end{array}$ & $\begin{array}{c}\text { Campus } \\
\quad \# 6\end{array}$ & $\begin{array}{c}\text { Campus } \\
\quad \# 7\end{array}$ & $\begin{array}{c}\text { Campus } \\
\quad \# 8\end{array}$ & $\begin{array}{c}\text { Campus } \\
\# 9\end{array}$ & $\begin{array}{c}\text { Campus } \\
\# 10\end{array}$ \\
\hline \multicolumn{12}{|l|}{ Employment } \\
\hline Not working & 43.6 & 38.0 & 38.8 & 42.4 & 36.8 & 28.8 & 24.3 & 52.4 & 44.8 & 53.3 & 37.2 \\
\hline Working 1-10 hrs/wk & 19.4 & 22.2 & 20.7 & 15.6 & 11.8 & 15.8 & 11.8 & 21.8 & 18.4 & 17.7 & 22.0 \\
\hline Working 11-20 hrs/wk & 25.1 & 21.6 & 25.9 & 26.7 & 26.4 & 34.1 & 23.7 & 20.6 & 23.1 & 20.1 & 30.6 \\
\hline Working 21-30 hrs/wk & 6.8 & 9.2 & 8.8 & 9.6 & 11.2 & 13.5 & 16.6 & 3.2 & 6.8 & 5.1 & 6.5 \\
\hline Working $>30 \mathrm{hrs} / \mathrm{wk}$ & 5.1 & 9.0 & 5.8 & 5.6 & 13.8 & 7.9 & 23.7 & 2.1 & 7.0 & 3.8 & 3.7 \\
\hline \multicolumn{12}{|l|}{ Monthly income } \\
\hline Income (\$1-\$249) & 19.5 & 25.0 & 23.6 & 18.6 & 17.1 & 14.3 & 14.2 & 21.9 & 23.9 & 19.4 & 16.1 \\
\hline Income (\$250-\$499) & 20.9 & 16.2 & 21.2 & 21.1 & 22.8 & 22.6 & 20.1 & 17.5 & 18.7 & 16.8 & 27.6 \\
\hline Income $(\$ 500-\$ 749)$ & 8.6 & 8.8 & 9.3 & 10.2 & 9.3 & 16.7 & 13.0 & 5.1 & 6.5 & 6.1 & 11.0 \\
\hline Income (\$750-\$999) & 3.7 & 4.7 & 3.9 & 4.7 & 4.4 & 8.2 & 5.3 & 1.8 & 2.7 & 2.3 & 4.8 \\
\hline Income $(\geq \$ 1000)$ & 4.9 & 8.8 & 4.3 & 5.2 & 10.8 & 10.2 & 25.4 & 2.2 & 5.2 & 3.7 & 4.1 \\
\hline \multicolumn{12}{|l|}{ Regional information } \\
\hline Rural area (pop under 2,500) & 12.3 & 12.5 & 14.8 & 8.9 & 19.0 & 3.6 & 21.9 & 8.7 & 22.3 & 13.5 & 12.6 \\
\hline Town/City (pop 2,500-19,999) & 30.6 & 34.3 & 32.8 & 34.1 & 34.1 & 27.7 & 24.3 & 28.7 & 30.1 & 30.3 & 30.9 \\
\hline City (pop 20,000-99,999) & 35.1 & 33.5 & 37.0 & 38.7 & 28.1 & 32.1 & 23.7 & 39.6 & 33.5 & 32.9 & 33.7 \\
\hline City (pop 100,000 or more) & 21.9 & 19.7 & 15.1 & 18.0 & 18.6 & 36.0 & 30.2 & 22.8 & 13.9 & 23.2 & 22.7 \\
\hline
\end{tabular}


Table 2C: Credit Characteristics of Students (by campus)

\begin{tabular}{|c|c|c|c|c|c|c|c|c|c|c|c|}
\hline Variable (mean/percentage) & $\begin{array}{c}\text { All } \\
\text { Students }\end{array}$ & $\begin{array}{c}\text { Campus } \\
\# 1\end{array}$ & $\begin{array}{c}\text { Campus } \\
\# 2\end{array}$ & $\begin{array}{c}\text { Campus } \\
\text { \#3 }\end{array}$ & $\begin{array}{l}\text { Campus } \\
\# 4\end{array}$ & $\underset{\# 5}{\text { Campus }}$ & $\begin{array}{c}\text { Campus } \\
\# 6\end{array}$ & $\begin{array}{c}\text { Campus } \\
\# 7\end{array}$ & $\begin{array}{c}\text { Campus } \\
\# 8\end{array}$ & $\begin{array}{c}\text { Campus } \\
\# 9\end{array}$ & $\begin{array}{c}\text { Campus } \\
\# 10\end{array}$ \\
\hline Have a credit card(s) & 72.4 & 74.7 & 73.9 & 71.0 & 72.6 & 77.4 & 76.3 & 73.2 & 70.1 & 72.4 & 69.8 \\
\hline \multicolumn{12}{|l|}{ Credit card usage } \\
\hline 4 or more credit cards & 18.9 & 20.5 & 22.3 & 22.1 & 22.3 & 28.1 & 32.0 & 15.9 & 20.5 & 16.2 & 16.8 \\
\hline Credit card debt $\geq \$ 1000$ & 15.7 & 17.9 & 16.6 & 21.0 & 27.9 & 25.2 & 32.5 & 10.5 & 20.5 & 14.8 & 11.5 \\
\hline Credit card debt $\geq \$ 3000$ & 7.5 & 7.2 & 7.3 & 10.2 & 16.3 & 13.7 & 21.9 & 4.3 & 10.3 & 6.6 & 5.1 \\
\hline Delinquent on payments & 6.2 & 5.1 & 5.6 & 9.0 & 13.3 & 9.9 & 10.1 & 4.4 & 9.5 & 5.7 & 3.6 \\
\hline Reached limit on credit cards & 15.3 & 15.2 & 14.7 & 18.5 & 23.9 & 21.4 & 25.4 & 11.8 & 19.0 & 16.6 & 11.5 \\
\hline Do not payoff balance & 24.0 & 23.6 & 28.3 & 32.1 & 40.4 & 31.9 & 44.4 & 17.6 & 33.9 & 21.9 & 17.2 \\
\hline \multicolumn{12}{|l|}{ Credit card(s) obtained: } \\
\hline Before beginning college & 36.4 & 45.0 & 36.3 & 33.3 & 33.6 & 34.0 & 29.6 & 38.4 & 35.4 & 33.4 & 37.9 \\
\hline First year of college & 26.4 & 22.6 & 26.5 & 26.7 & 27.3 & 32.7 & 26.6 & 26.4 & 24.2 & 30.3 & 22.1 \\
\hline After first year of college & 10.6 & 8.4 & 11.9 & 11.9 & 12.6 & 11.5 & 20.1 & 9.3 & 11.7 & 9.4 & 10.4 \\
\hline \multicolumn{12}{|l|}{ Credit card(s) acquired: } \\
\hline Through a mail application & 25.1 & 24.0 & 28.2 & 29.8 & 27.7 & 31.9 & 37.9 & 24.9 & 29.7 & 18.7 & 21.8 \\
\hline At a bank/financial institution & 20.8 & 21.2 & 19.5 & 11.8 & 17.7 & 13.9 & 18.9 & 19.5 & 13.8 & 27.9 & 25.7 \\
\hline From parents & 10.7 & 12.7 & 10.3 & 6.5 & 6.3 & 9.0 & 3.0 & 15.8 & 7.5 & 9.0 & 10.0 \\
\hline Online & 5.5 & 5.8 & 4.4 & 6.9 & 5.4 & 7.0 & 6.5 & 5.6 & 5.3 & 6.0 & 4.6 \\
\hline At a campus table & 4.6 & 3.5 & 4.0 & 8.9 & 7.9 & 8.2 & 4.1 & 2.9 & 6.0 & 6.2 & 2.2 \\
\hline At a retail store & 2.8 & 4.7 & 4.3 & 3.3 & 4.2 & 3.6 & 4.7 & 1.7 & 4.0 & 1.9 & 2.5 \\
\hline Over the phone & 2.6 & 2.9 & 3.0 & 3.1 & 2.9 & 2.8 & 1.2 & 2.2 & 3.5 & 2.3 & 2.3 \\
\hline Other & 1.0 & 0.6 & 1.0 & 1.2 & 1.3 & 1.4 & 0.6 & 1.0 & 1.0 & 0.9 & 1.0 \\
\hline
\end{tabular}

Note: Percentages may not sum to 100 due to rounding. 
Table 2C (conti.): Credit Characteristics of Students (by campus)

\begin{tabular}{|c|c|c|c|c|c|c|c|c|c|c|c|}
\hline Variable (mean/percentage) & $\begin{array}{c}\text { All } \\
\text { Students }\end{array}$ & $\begin{array}{c}\text { Campus } \\
\quad \# 1\end{array}$ & $\begin{array}{c}\text { Campus } \\
\quad \# 2\end{array}$ & $\begin{array}{c}\text { Campus } \\
\quad \# 3\end{array}$ & $\begin{array}{c}\text { Campus } \\
\quad \# 4\end{array}$ & $\begin{array}{c}\text { Campus } \\
\# 5\end{array}$ & $\begin{array}{c}\text { Campus } \\
\quad \# 6\end{array}$ & $\begin{array}{c}\text { Campus } \\
\quad \# 7\end{array}$ & $\begin{array}{c}\text { Campus } \\
\quad \# 8\end{array}$ & $\begin{array}{c}\text { Campus } \\
\# 9\end{array}$ & $\begin{array}{c}\text { Campus } \\
\# 10\end{array}$ \\
\hline \multicolumn{12}{|l|}{ Financial aid } \\
\hline Receives financial aid & 71.7 & 94.5 & 72.4 & 74.7 & 82.2 & 70.3 & 85.2 & 67.8 & 82.5 & 70.6 & 67.1 \\
\hline Federal student loans & 48.2 & 73.5 & 53.7 & 54.2 & 58.3 & 43.6 & 58.6 & 39.8 & 66.3 & 49.4 & 43.3 \\
\hline Federal parent loans & 10.1 & 14.4 & 9.7 & 9.1 & 5.5 & 4.9 & 5.9 & 13.3 & 9.7 & 17.2 & 5.4 \\
\hline Alternative loans & 6.2 & 12.9 & 5.9 & 7.0 & 4.9 & 3.8 & 4.7 & 5.0 & 9.3 & 8.9 & 5.5 \\
\hline Federal work-study & 11.6 & 19.9 & 7.1 & 9.8 & 26.9 & 8.4 & 13.0 & 11.8 & 9.3 & 8.8 & 11.8 \\
\hline Need-based grants & 25.1 & 31.6 & 25.1 & 30.7 & 45.1 & 38.0 & 41.4 & 21.8 & 36.6 & 21.3 & 14.5 \\
\hline Scholarships & 38.3 & 82.7 & 24.4 & 26.4 & 27.9 & 24.8 & 33.7 & 44.3 & 28.6 & 44.6 & 43.5 \\
\hline Tuition waiver & 5.5 & 4.1 & 6.9 & 8.6 & 8.9 & 5.7 & 7.1 & 8.3 & 7.2 & 2.8 & 1.0 \\
\hline Financial aid $\geq \$ 10,000$ & 18.1 & 28.1 & 18.9 & 18.7 & 20.7 & 13.9 & 19.5 & 14.0 & 21.3 & 22.5 & 18.4 \\
\hline Financial aid not enough & 44.3 & 45.2 & 51.4 & 40.6 & 48.8 & 54.6 & 45.1 & 42.2 & 50.7 & 45.0 & 35.4 \\
\hline \multicolumn{12}{|l|}{ Other debt } \\
\hline Owes other debt & 28.9 & 29.6 & 34.5 & 35.9 & 47.4 & 34.8 & 57.4 & 21.1 & 42.1 & 27.7 & 21.7 \\
\hline Car loan & 11.3 & 14.2 & 17.3 & 16.3 & 23.8 & 13.7 & 37.3 & 5.2 & 20.2 & 10.8 & 6.0 \\
\hline Mortgage & 2.3 & 4.7 & 2.6 & 2.0 & 7.6 & 2.9 & 16.6 & 0.6 & 5.1 & 1.8 & 1.0 \\
\hline Informal loan (family/friends) & 8.2 & 8.0 & 8.5 & 7.9 & 9.9 & 8.0 & 11.2 & 6.8 & 8.0 & 8.4 & 9.0 \\
\hline Private loan from bank & 3.2 & 5.3 & 3.5 & 4.2 & 6.3 & 2.9 & 4.1 & 1.9 & 6.0 & 3.0 & 2.4 \\
\hline Installment loan & 1.9 & 2.9 & 2.3 & 2.1 & 4.1 & 2.9 & 8.3 & 0.9 & 3.0 & 1.7 & 1.1 \\
\hline Owes other debt $\geq \$ 1000$ & 16.0 & 1.8 & 19.7 & 19.5 & 31.1 & 19.2 & 40.8 & 9.5 & 25.4 & 15.3 & 11.7 \\
\hline
\end{tabular}


Table 3C: Preferences for the Delivery of Financial Information (by campus)

\begin{tabular}{|c|c|c|c|c|c|c|c|c|c|c|c|}
\hline Variable (mean/percentage) & $\begin{array}{c}\text { All } \\
\text { Students }\end{array}$ & $\begin{array}{c}\text { Campus } \\
\quad \# 1\end{array}$ & $\begin{array}{c}\text { Campus } \\
\quad \# 2\end{array}$ & $\begin{array}{c}\text { Campus } \\
\quad \# 3\end{array}$ & $\begin{array}{c}\text { Campus } \\
\quad \# 4\end{array}$ & $\begin{array}{l}\text { Campus } \\
\quad \# 5\end{array}$ & $\begin{array}{c}\text { Campus } \\
\quad \# 6\end{array}$ & $\begin{array}{c}\text { Campus } \\
\quad \# 7\end{array}$ & $\begin{array}{c}\text { Campus } \\
\quad \# 8\end{array}$ & $\begin{array}{c}\text { Campus } \\
\# 9\end{array}$ & $\begin{array}{c}\text { Campus } \\
\# 10\end{array}$ \\
\hline \multicolumn{12}{|l|}{ How you like to receive info? } \\
\hline One-on-one discussion & 51.9 & 53.2 & 53.7 & 52.1 & 56.1 & 52.1 & 54.4 & 48.6 & 50.5 & 51.6 & 53.8 \\
\hline On the Internet & 47.7 & 46.2 & 46.0 & 45.8 & 45.0 & 52.0 & 40.2 & 51.1 & 41.4 & 48.4 & 46.3 \\
\hline Packet of printed materials & 40.8 & 42.1 & 42.2 & 42.1 & 40.2 & 41.6 & 39.1 & 41.0 & 41.1 & 40.8 & 39.3 \\
\hline Campus workshop/seminar & 21.6 & 24.0 & 17.7 & 22.3 & 20.2 & 22.8 & 16.0 & 24.1 & 19.0 & 21.1 & 21.2 \\
\hline Formal college course & 12.4 & 14.6 & 10.6 & 9.3 & 9.6 & 10.7 & 8.3 & 14.4 & 11.2 & 12.9 & 13.0 \\
\hline \multicolumn{12}{|l|}{ Who you like to receive info from? } \\
\hline Financial experts/professionals & 58.2 & 58.9 & 57.1 & 59.4 & 60.3 & 63.0 & 61.5 & 57.0 & 53.0 & 57.9 & 59.1 \\
\hline Parents & 49.8 & 52.2 & 49.4 & 41.4 & 37.6 & 36.3 & 34.3 & 54.9 & 42.3 & 50.3 & 57.0 \\
\hline Financial aid counselors & 44.7 & 40.7 & 47.2 & 51.9 & 51.1 & 51.3 & 47.3 & 41.2 & 47.4 & 45.9 & 40.1 \\
\hline Other students/peers & 18.3 & 17.2 & 15.5 & 17.1 & 16.7 & 23.0 & 15.4 & 20.6 & 13.9 & 16.9 & 18.7 \\
\hline Professors & 16.4 & 21.6 & 15.5 & 15.2 & 12.9 & 16.0 & 14.8 & 18.2 & 15.0 & 15.8 & 16.5 \\
\hline Obtain information on my own & 16.5 & 15.2 & 13.8 & 15.4 & 18.2 & 19.9 & 21.3 & 16.7 & 16.0 & 16.9 & 15.8 \\
\hline \multicolumn{12}{|l|}{ Where you have found useful info? } \\
\hline Parents & 73.5 & 74.5 & 77.3 & 70.6 & 60.6 & 60.8 & 55.0 & 78.7 & 68.3 & 74.5 & 76.2 \\
\hline Friends & 21.7 & 17.3 & 19.3 & 23.3 & 23.1 & 27.9 & 25.4 & 22.0 & 20.0 & 21.3 & 20.6 \\
\hline Financial institutions & 18.0 & 20.3 & 16.1 & 17.1 & 19.6 & 19.5 & 29.0 & 14.2 & 17.9 & 18.1 & 21.9 \\
\hline Internet & 14.3 & 14.8 & 11.6 & 15.6 & 17.4 & 19.7 & 21.3 & 13.5 & 13.2 & 15.8 & 12.5 \\
\hline High school or college course & 11.8 & 13.8 & 13.0 & 15.2 & 11.6 & 12.4 & 8.9 & 11.9 & 12.4 & 10.6 & 10.7 \\
\hline Books, magazines, newspapers & 10.0 & 10.3 & 9.5 & 11.7 & 13.1 & 14.7 & 14.2 & 9.4 & 10.0 & 9.2 & 8.3 \\
\hline $\mathrm{TV}$ and radio & 4.4 & 3.9 & 3.4 & 4.6 & 6.4 & 7.7 & 2.4 & 4.3 & 5.0 & 4.2 & 3.3 \\
\hline Non-profits & 3.4 & 3.9 & 2.9 & 2.3 & 6.9 & 4.9 & 7.7 & 2.9 & 4.4 & 3.0 & 2.6 \\
\hline Have not gone to find info & 10.2 & 9.7 & 8.7 & 11.0 & 13.0 & 12.3 & 11.8 & 9.6 & 11.1 & 9.3 & 9.9 \\
\hline
\end{tabular}

Note: Percentages do not sum to 100 percent for each category because students could select more than one category. 
Table 4C: Knowledge and Preferences for Financial Education Topics (by campus)

\begin{tabular}{|c|c|c|c|c|c|c|c|c|c|c|c|}
\hline Variable (mean/percentage) & $\begin{array}{c}\text { All } \\
\text { Students }\end{array}$ & $\begin{array}{c}\text { Campus } \\
\# 1\end{array}$ & $\begin{array}{c}\text { Campus } \\
\quad \# 2\end{array}$ & $\begin{array}{c}\text { Campus } \\
\quad \# 3\end{array}$ & $\begin{array}{c}\text { Campus } \\
\# 4\end{array}$ & $\begin{array}{c}\text { Campus } \\
\# 5\end{array}$ & $\begin{array}{c}\text { Campus } \\
\text { \#6 }\end{array}$ & $\begin{array}{l}\text { Campus } \\
\quad \# 7\end{array}$ & $\begin{array}{c}\text { Campus } \\
\# 8\end{array}$ & $\begin{array}{c}\text { Campus } \\
\quad \# 9\end{array}$ & $\begin{array}{c}\text { Campus } \\
\# 10\end{array}$ \\
\hline \multicolumn{12}{|l|}{ Financial topic is important } \\
\hline Personal finance and budgeting & 87.0 & 86.2 & 87.0 & 89.2 & 89.5 & 87.8 & 89.3 & 85.6 & 88.7 & 89.1 & 85.2 \\
\hline Credit cards and terms & 59.1 & 60.6 & 61.5 & 62.6 & 64.6 & 67.8 & 59.2 & 57.9 & 61.9 & 58.1 & 53.6 \\
\hline Shopping for a car loan & 33.2 & 36.3 & 39.7 & 42.1 & 43.6 & 38.5 & 50.9 & 27.3 & 47.1 & 34.6 & 23.9 \\
\hline Financing a college education & 77.6 & 82.5 & 78.7 & 83.0 & 83.5 & 82.9 & 81.7 & 72.5 & 84.4 & 76.6 & 76.3 \\
\hline Saving and investing & 83.4 & 85.0 & 84.9 & 83.3 & 81.6 & 85.0 & 81.1 & 83.0 & 84.3 & 85.9 & 81.3 \\
\hline Planning for retirement & 42.7 & 43.3 & 42.6 & 41.5 & 50.5 & 44.7 & 49.1 & 39.3 & 48.4 & 48.0 & 38.2 \\
\hline \multicolumn{12}{|l|}{ Understand the financial topic } \\
\hline Personal finance and budgeting & 59.5 & 57.9 & 61.0 & 61.6 & 63.0 & 59.4 & 60.9 & 57.2 & 61.4 & 61.9 & 57.9 \\
\hline Credit cards and terms & 51.9 & 53.2 & 52.5 & 56.0 & 57.5 & 58.2 & 59.8 & 49.7 & 54.6 & 51.5 & 48.2 \\
\hline Shopping for a car loan & 21.6 & 18.9 & 26.2 & 27.5 & 35.1 & 27.4 & 42.6 & 15.6 & 33.6 & 22.5 & 14.2 \\
\hline Financing a college education & 48.3 & 49.3 & 48.7 & 52.7 & 56.8 & 52.3 & 59.8 & 42.8 & 54.4 & 46.4 & 48.2 \\
\hline Saving and investing & 51.8 & 53.8 & 56.4 & 54.0 & 52.8 & 52.0 & 50.9 & 49.4 & 56.4 & 55.2 & 47.8 \\
\hline Planning for retirement & 19.0 & 16.0 & 18.5 & 21.9 & 25.8 & 21.1 & 21.9 & 16.4 & 23.3 & 21.3 & 16.2 \\
\hline
\end{tabular}


Table 5C: Preferences for Personal Finance Courses (by campus)

\begin{tabular}{|c|c|c|c|c|c|c|c|c|c|c|c|}
\hline Variable (mean/percentage) & $\begin{array}{c}\text { All } \\
\text { Students }\end{array}$ & $\begin{array}{c}\text { Campus } \\
\# 1\end{array}$ & $\begin{array}{c}\text { Campus } \\
\# 2\end{array}$ & $\begin{array}{c}\text { Campus } \\
\quad \# 3\end{array}$ & $\begin{array}{c}\text { Campus } \\
\# 4\end{array}$ & $\begin{array}{c}\text { Campus } \\
\# 5\end{array}$ & $\begin{array}{c}\text { Campus } \\
\text { \#6 }\end{array}$ & $\begin{array}{c}\text { Campus } \\
\# 7\end{array}$ & $\begin{array}{c}\text { Campus } \\
\# 8\end{array}$ & $\begin{array}{c}\text { Campus } \\
\quad \# 9\end{array}$ & $\begin{array}{c}\text { Campus } \\
\# 10\end{array}$ \\
\hline Took a personal finance course & 27.2 & 28.5 & 31.8 & 29.9 & 29.7 & 24.7 & 24.3 & 29.4 & 32.1 & 22.6 & 23.4 \\
\hline \multicolumn{12}{|l|}{ Would you register for course? } \\
\hline Yes, only if class was free & 27.9 & 33.3 & 30.6 & 29.4 & 32.6 & 32.6 & 33.1 & 23.6 & 27.8 & 25.8 & 29.1 \\
\hline Yes, only if for course credit & 32.4 & 31.8 & 32.0 & 31.4 & 27.4 & 31.8 & 28.4 & 36.1 & 33.5 & 34.2 & 29.1 \\
\hline Yes, regardless of cost or credit & 11.5 & 11.5 & 8.6 & 10.8 & 10.9 & 10.2 & 8.3 & 12.5 & 9.7 & 11.2 & 13.3 \\
\hline No & 27.9 & 23.2 & 28.6 & 28.1 & 28.8 & 25.2 & 29.6 & 27.6 & 28.6 & 28.7 & 28.3 \\
\hline \multicolumn{12}{|l|}{ Would you register for online course? } \\
\hline Yes, only if class was free & 33.6 & 36.8 & 36.7 & 33.9 & 36.2 & 38.9 & 40.8 & 29.1 & 33.2 & 35.2 & 33.1 \\
\hline Yes, only if for course credit & 22.4 & 24.0 & 23.4 & 22.5 & 17.9 & 21.5 & 23.7 & 25.4 & 22.2 & 19.9 & 21.9 \\
\hline Yes, regardless of cost or credit & 9.8 & 9.2 & 8.2 & 9.9 & 8.2 & 8.5 & 14.2 & 10.6 & 8.4 & 8.2 & 12.1 \\
\hline No & 34.0 & 29.4 & 31.5 & 33.3 & 37.5 & 30.8 & 21.3 & 34.7 & 36.0 & 36.5 & 32.8 \\
\hline
\end{tabular}


Table 6C: The Consequences of Student Financial Strain (by campus)

\begin{tabular}{|c|c|c|c|c|c|c|c|c|c|c|c|}
\hline Variable (mean/percentage) & $\begin{array}{c}\text { All } \\
\text { Students }\end{array}$ & $\begin{array}{c}\text { Campus } \\
\quad \# 1\end{array}$ & $\begin{array}{c}\text { Campus } \\
\quad \# 2\end{array}$ & $\begin{array}{l}\text { Campus } \\
\quad \# 3\end{array}$ & $\begin{array}{l}\text { Campus } \\
\quad \# 4\end{array}$ & $\begin{array}{l}\text { Campus } \\
\quad \# 5\end{array}$ & $\begin{array}{l}\text { Campus } \\
\quad \# 6\end{array}$ & $\begin{array}{l}\text { Campus } \\
\quad \# 7\end{array}$ & $\begin{array}{l}\text { Campus } \\
\quad \# 8\end{array}$ & $\begin{array}{l}\text { Campus } \\
\quad \# 9\end{array}$ & $\begin{array}{l}\text { Campus } \\
\quad \# 10\end{array}$ \\
\hline \multicolumn{12}{|l|}{$\begin{array}{l}\text { Likelihood financial situation will } \\
\text { affect completion of degree.... }\end{array}$} \\
\hline Likely & 12.4 & 11.9 & 12.7 & 21.0 & 16.8 & 19.0 & 17.8 & 8.2 & 19.2 & 11.4 & 8.2 \\
\hline Somewhat likely & 18.0 & 18.3 & 19.0 & 22.3 & 21.5 & 26.0 & 28.4 & 13.9 & 22.6 & 19.0 & 14.6 \\
\hline Not likely & 69.5 & 69.8 & 68.2 & 56.6 & 61.6 & 54.8 & 53.8 & 77.8 & 58.1 & 69.6 & 77.1 \\
\hline \multicolumn{12}{|l|}{ As a result of financial situation.... } \\
\hline Reduced number of credit hours & 15.9 & 13.6 & 16.0 & 18.5 & 29.6 & 23.7 & 34.9 & 10.2 & 18.9 & 13.7 & 16.6 \\
\hline Dropped out for a semester & 5.6 & 5.1 & 6.0 & 8.1 & 13.4 & 9.8 & 22.5 & 2.2 & 10.8 & 4.3 & 3.5 \\
\hline Difficulty concentrating on studies & 33.2 & 27.7 & 34.8 & 41.4 & 52.4 & 45.3 & 47.0 & 24.2 & 40.5 & 32.5 & 31.3 \\
\hline Losing sleep/physical discomfort & 26.9 & 23.6 & 29.9 & 35.7 & 45.6 & 36.3 & 40.8 & 18.9 & 35.5 & 25.7 & 23.5 \\
\hline
\end{tabular}

